\title{
The Mandalovoo-Gurvansayhan terranes in the southern Gobi of Mongolia: new insights from the Bayankhoshuu Ruins section
}

\author{
A. Munkhjargal ${ }^{1,2}$ (D) P. Königshof ${ }^{2}$ (D) J. A. Waters ${ }^{3} \cdot$ S. K. Carmichael $^{3} \cdot$ S. Gonchigdorj $^{1} \cdot$ H. Thassanapak $^{4} \cdot$ \\ M. Udchachon ${ }^{4} \cdot$ Sh. Davaanyam ${ }^{5}$
}

Received: 26 August 2020 / Accepted: 1 December 2020 / Published online: 17 February 2021

(C) The Author(s) 2021

\begin{abstract}
The Bayankhoshuu Ruins section in southern Mongolia is characterized by strongly thrusted and folded sequences. Overall, three sections ranging from Ordovician to Carboniferous rocks were studied. Facies analysis combined with stratigraphic data provide improved lithostratigraphic descriptions of Palaeozoic successions in the Mushgai region. The overall marine sedimentary sequence is punctuated by volcanic rocks-basaltic lava of Silurian and Middle Devonian age and volcaniclastic bentonite and tuff in the Middle to Late Devonian and Mississippian suggesting an island arc setting. The Minjin Member of the Botuulkhudag Formation (Middle Devonian to Late Devonian) is primarily composed of thick basaltic and subaerial volcanic rocks with minor silicified siltstone and chert inclusions. Thicker successions of limestone occur in the Ordovician/Silurian, Early Devonian, and the Mississippian. The macrofauna is scarce, except distinct limestone horizons where different fossil groups were recognized. Microfossils, such as radiolarians and conodonts, are scarce and generally poorly preserved. However, based on the re-study of collections from earlier publications and new conodont data, a more detailed biostratigraphic record of the Khoyormod, Botuulkhudag, and Arynshand formations of the Bayankhoshuu Ruins section can be developed. For instance, the Arynshand Formation likely ranges from the late Bispathodus ultimus conodont biozone to the Scaliognathus anchoralis-Doliognathus latus conodont biozone. A tectonic breccia occurs in the early Mississippian and is overlain by a red shale of remarkable thickness at the top of this formation which points to subaerial exposure in the early Mississippian (near the Tournaisian/Visean transition). Due to strong tectonic overprint and/or facies, some unconformities/hiatuses occur. Most strata are intensively folded and faulted, ranging from centimeter to meter scale. Overall, deposition likely occurred on either the Mandalovoo or Gurvansayhan Terrane.
\end{abstract}

This is a contribution to a special series on "The Central Asian Orogenic Belt (CAOB) during Late Devonian: new insights from southern Mongolia."

A. Munkhjargal

ariuka.munkhjargal@senckenberg.de

P. Königshof

peter.koenigshof@senckenberg.de

J. A. Waters

watersja@appstate.edu

S. K. Carmichael

carmichaelsk@appstate.edu

S. Gonchigdorj

sersmaa@gmail.com

H. Thassanapak

bthaithip@yahoo.com

M. Udchachon

mongkol.c@msu.ac.th
Sh. Davaanyam

sharav0516@gmail.com

1

Mongolian University of Science and Technology, 8th khoroo, Baga toiruu 34, Sukhbaatar District, Ulaanbaatar 14191, Mongolia

2 Senckenberg Research Institute and Natural History Museum, Senckenberganlage 25, 60325 Frankfurt, Germany

3 Department of Geological and Environmental Sciences, Appalachian State University, 572 Rivers St., Boone, NC 28608, USA

4 Paleontological Research and Education Center, Mahasarakham University, Mahasarakham 44150, Thailand

5 Institute of Geology, Mongolian Academy of Science, Labor union street, Songinokhairkhan district, Ulaanbaatar 18080, Mongolia 
Keywords Central Asian Orogenic Belt (CAOB) $\cdot$ Mongolia $\cdot$ Palaeozoic biostratigraphy $\cdot$ Volcanism $\cdot$ Hemipelagic/pelagic facies · Island arc

\section{Introduction and geological frame}

The Central Asian Orogenic Belt (CAOB) is the world's largest Palaeozoic accretionary orogenic belt. The CAOB covers a huge area which extends from Kazakhstan in the west, through Kyrgyzstan, Uzbekistan, northwestern China, the Altai-Sayan region and Transbaikalia in Russia, Mongolia, and northeastern China to the Russian Far East. The accretionary system includes oceanic, intra-oceanic, and numerous fragments of Precambrian microcontinents and collisional and post-collisional complexes as well as continental margin arc terranes. In the last two decades, significant progress has been made in understanding the complex plate tectonic dynamics by studies on geochronological, geochemical, and isotope dating preferably from magmatic and metamorphic rocks (Badarch et al. 2002; Windley et al. 2007; Xiao et al. 2010; Kröner et al. 2014; Xiao and Santosh 2014; Safonova et al. 2017; Yang et al. 2019, among others). Papers outlining the terranes and tectonic history of Mongolia do not necessarily have broad generalizations about the geology of specific areas. Although several petrological, geochemical, and structural studies were conducted to get a better understanding on the complex framework of the $\mathrm{CAOB}$, detailed sedimentological and stratigraphical descriptions are scarce. The primary references for the geology of the studied area (Bayankhoshuu Ruins; Umnugobi Province, southern Mongolia) is published in the guidebook for the 2001 joint meeting of IGCP 410 and 421 (Minjin et al. 2001) and in later publications by Wang et al. (2003a,b, 2005).

The Bayankhoshuu Ruins section was chosen in order to compare Palaeozoic strata (primarily Devonian and Carboniferous successions) with successions in western Mongolia (Hushoot Shiveetiin gol section, Munkhjargal et al. this issue) and to generally increase the resolution of the biostratigraphy, lithostratigraphy, and sedimentology of this important section. In late July and early August 2019, the group measured sections from the Ordovician, Silurian to Devonian, and Carboniferous (Mississippian) near the Olon Ovoot gold mine ( $44^{\circ} 09^{\prime} 44^{\prime \prime}$; E $\left.104^{\circ} 22^{\prime} 28^{\prime \prime}\right)$. More than $1 \mathrm{~km}$ of section was measured (some parts of the section were summarized due to very rare facies differences), and about $610 \mathrm{~m}$ was measured in detail. Selected conodont samples were processed in the field with the hope of obtaining preliminary biostratigraphic information of critical intervals within the section. Overall, the fauna of the Bayankhoshuu Ruins section is scarce and fossils are poorly preserved due to tectonic overprint except some distinct horizons in the lower Mississippian.

This contribution presents results of the fieldwork, which supply an insight into the complex geology of the southern
Gobi of Mongolia and provide additional information on the placement of the succession within the Palaeozoic Terrane scheme for Mongolia. Furthermore, this report provides new information of the complex relationships between the sedimentary and volcanic sequences in the Bayankhoshuu Ruins area, southern Mongolia. Additionally, the team hopes that work in progress can also provide insight into global Palaeozoic events by providing detailed analyses of sequences that were previously known only generally.

\section{Palaeozoic Terranes in Mongolia}

The CAOB is the world's largest Palaeozoic accretionary orogenic belt and likely evolved in a similar fashion to the modern Pacific. Windley et al. (2007) favored an island archipelago model similar to modern Indonesia for island arc terranes in the CAOB including Mongolia. This accretionary system has evolved over at least 800 million years, from the Neoproterozoic time until the Cenozoic (Safonova et al. 2017). The CAOB formed by the suturing of the Palaeo-Asian Ocean (PAO) and multi-stage Palaeozoic collisions of the East European, Siberian, North China, and Tarim cratons. The subduction of the PAO continued during the Middle and Late Palaeozoic before final closure of this ocean and its Turkestan and Junggar branches during the Late Palaeozoic to the Mesozoic (Windley et al. 2007; Donskaya et al. 2013; Yang et al. 2015; Safonova et al. 2017). Mongolia lies in the center of the CAOB. Badarch et al. (2002) recognized 44 different terranes - cratonic, metamorphic, passive margin, island arc, forearc/backarc, accretionary complex, or ophiolites ranging in age from the Proterozoic through the Phanerozoic. The Devonian was one of the primary times of terrane accretion. Traditionally, Mongolia is divided into a northern and southern domain by the Main Mongolian Lineament which separates dominantly Precambrian and Lower Palaeozoic rocks to the north from Lower and Upper Palaeozoic rocks to the south (Fig. 1).

We conducted fieldwork in the northern part of the Gurvansayhan Terrane (Fig. 1, \#8) or in the southernmost part of the Mandalovoo Terrane (Fig. 1, \#2) in the scheme of Badarch et al. (2002). The geographic location of the field area is on the terrane boundary as drawn by Badarch et al. (2002). These two terranes are separated from the Idermeg Terrane by the Gobi Altai Terrane (Fig. 1, \#1). The terrane descriptions below are summarized from Badarch et al. (2002).

The Idermeg Terrane formed in the Neoproterozoic to Cambrian and is interpreted to represent a Palaeozoic passive continental margin. The post-accretionary complexes include Devonian to Permian and Triassic-Jurassic volcanic and sedimentary rocks, and minor limestone. The backarc/ 
forearc basins contain dominantly Lower Palaeozoic thick volcaniclastic and sedimentary successions, and minor melanges of ultramafic and volcanic rocks. This terrane is mainly distinguished by their proximity to island arcs, by their composition and thickness of basin sediments, and by their geochemical signatures of volcanic rocks.

The Gobi Altai Terrane is a narrow terrane, located south of the Idermeg Terrane. It consists of Cambrian (?) greenschist facies metamorphosed sandstone, mudstone, tuff, and minor volcanic rocks, Ordovician to Silurian sandstone, argillite, shallow-marine fossiliferous limestone, minor conglomerate, olistostrome, Devonian-Mississippian conglomerate, sandstone, siltstone, fossiliferous limestone, pillow basalt, andesite and tuff, overlain by Pennsylvanian, Permian-Triassic volcanic and sedimentary rocks. The Ordovician-Silurian sandstones are mostly mature and quartzitic. Uppermost Silurian conglomerates contain plutonic and volcanic clasts.

The Mandalovoo Terrane and the Gurvansayhan Terrane (Fig. 1) are island arc terranes and consist mainly of ophiolites, tholeiitic to calc-alkaline volcanic and volcaniclastic rocks. The Mandalovoo Terrane is a narrow belt which lies to the south of the Idermeg Terrane. It contains a stratigraphic succession of Ordovician to Carboniferous volcanic and sedimentary rocks including Ordovician and Silurian sandstone, argillite, fossiliferous limestone, Lower-Middle Devonian conglomerate, sandstone, shallow-marine fossil-rich limestone, felsic tuff, Upper Devonian pillow basalt, andesite, tuff, volcaniclastic sandstone, chert, and Mississippian (Lower Carboniferous) marine sedimentary rocks. Geochemical data from pillow lavas indicate that the basalts were erupted in a subduction zone setting

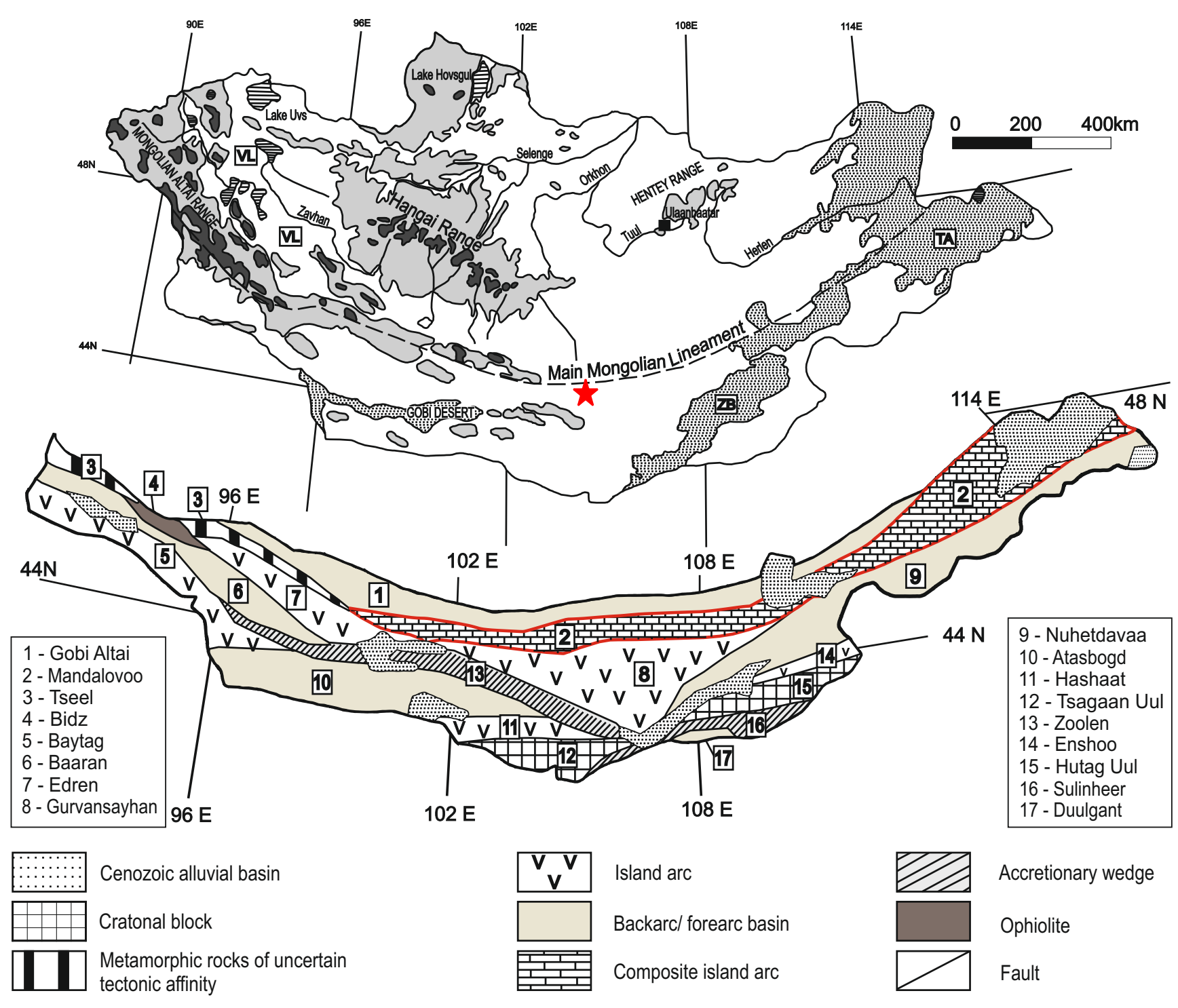

Fig. 1 Topographic map of Mongolia with location of the main Mongolian lineament and the southern structural units/terranes south of the main Mongolian lineament. Modified after Badarch et al. (2002). Asterisk marks the research area 
(Lamb and Badarch 2001). Palaeomagnetic results suggest that the Devonian volcanic arc was near the Palaeoequator and drifted $40^{\circ}$ northwards and was rotated $75^{\circ}$ clockwise (Fig. 2; Safonova et al. 2017).

The Gurvansayhan Terrane lies south of the Mandalovoo Terrane and is bordered by the Zoolen accretionary wedge in the southwest (Fig. 1). The terrane is composed of ophiolites, melanges, Ordovician-Silurian greenschist facies metamorphosed sandstone, argillite, chert, volcaniclastic rocks, Upper Silurian-Lower Devonian radiolarian chert, tholeiitic pillow basalt, andesite, tuff, Middle Devonian-Mississippian volcaniclastic rocks, chert containing Frasnian conodonts, and minor olistostrome with coral limestone clasts. The major and trace element geochemistry of Devonian basalt indicate volcanism in an arc environment (Ruzhentsev et al. 1992; Lamb and Badarch 2001). The structure of the terrane is complex and dominated by imbricate thrust sheets, dismembered blocks and melanges containing pillow lavas, fossiliferous limestone, sandstone, gabbro, diabase dykes, and amphibolite. The terrane is overlain by Carboniferous, Permian, Jurassic, and Cretaceous volcanic and sedimentary rocks.

Within the model proposed by Badarch et al. (2002) and modified by Helo et al. (2006), the Idermeg Terrane formed a cratonic nucleus around which younger terranes accreted. The Gobi Altai Terrane is made up of remnants of a rejuvenated old microcontinent associated with a backarc basin similar to a Japan-type magmatic arc. The Gurvansayhan Terrane has an origin in a juvenile island arc forearc setting. The accretion history of the terranes is complex with no simple north-tosouth progression of volcanism. In the Gurvansayhan Terrane, existing age data suggest a south-to-north accretion.

\section{CAOB and intra-oceanic arc systems}

Safonova et al. (2017) recognized 21 intra-oceanic arc systems in the CAOB associated with the closure of the Palaeo-
Asian Ocean and its branches. Intra-oceanic arcs (IOAs) form at Pacific-type convergent margins, in the upper plate, when the subducting plate submerges to the depths of melting, i.e., to ca. $50-100 \mathrm{~km}$. Based on publications by Badarch et al. (2002) and Helo et al. (2006), Safonova et al. (2017) identified an intra-oceanic arc in the Gurvansayhan-Zoolen terranes dating from the Late Silurian-Late Devonian (Fig. 3, \#17). The Gurvansayhan-Zoolen arc extends for a distance of more than $800 \mathrm{~km}$, making it one of the longest intra-oceanic arc systems in the CAOB. The Gurvansayhan island arc terrane is dominated by Silurian-Devonian island arc tholeiites and andesites and Middle Devonian volcaniclastic rocks. The arc units are covered by middle Carboniferous terrigenous sediments. The Zoolen Terrane was regarded as accretionary by Badarch et al. (2002), but Helo et al. (2006) interpreted it as an island arc.

The Zoolen Terrane is ca. $500 \mathrm{~km}$ long and up to $80 \mathrm{~km}$ wide. The volcanic rocks of the Gurvansayhan and Zoolen terranes are dominated by andesitic and basaltic varieties of boninitic, tholeiitic, and calc-alkaline series. The basalts have low $\mathrm{TiO}_{2}(0.5-1.3 \mathrm{wt} \%)$ and high $\mathrm{Mg}$, indicating near primary mantle-derived compositions. The andesites are moderately fractionated with $\mathrm{Mg}$ numbers of 50-60. There are andesites with high $\mathrm{MgO}(7.1 \mathrm{wt} \%)$ and $\mathrm{SiO}_{2}(60 \mathrm{wt} \%)$, i.e., similar to boninites (Helo et al. 2006). The calc-alkaline volcanics (andesites to rhyolites) are characterized by differentiated REE and concave HREE patterns which is typical of thick and mature island arcs. The tholeiitic basalts have low $\mathrm{Th} / \mathrm{Nb}$ (0.3) and low-enriched LREE (Helo et al. 2006) suggesting a very small amount of recycled sediments that is typical of immature island arcs (Stern and Scholl 2010). The Gurvansayhan and Zoolen volcanics are enriched in light REE and depleted in HFSE. Conclusively, the geochemical data in combination with high initial $\varepsilon$ Nd-values of ca. +6 to +9 (Helo et al. 2006; Table 2) are consistent with a juvenile intra-oceanic arc. There are also volcanic varieties compositionally similar to adakites, which, together with boninites,
Fig. 2 Plate tectonic reconstruction of the Palaeo-Asian Ocean during the Late Devonian published in Safonova et al. (2017; see references therein). Abbreviations for continental blocks: CM, Central Mongolian; Dz, Dzabkhan (Baydrag); SG, South Gobi; JR, Junggar; KAZ, Kazakhstan; NC, North China; NT, North Tienshan; ST, South China; RA, Rudny Altai; SIB, Siberian Craton. South Gobi at that time is placed around $40^{\circ}$ to the north

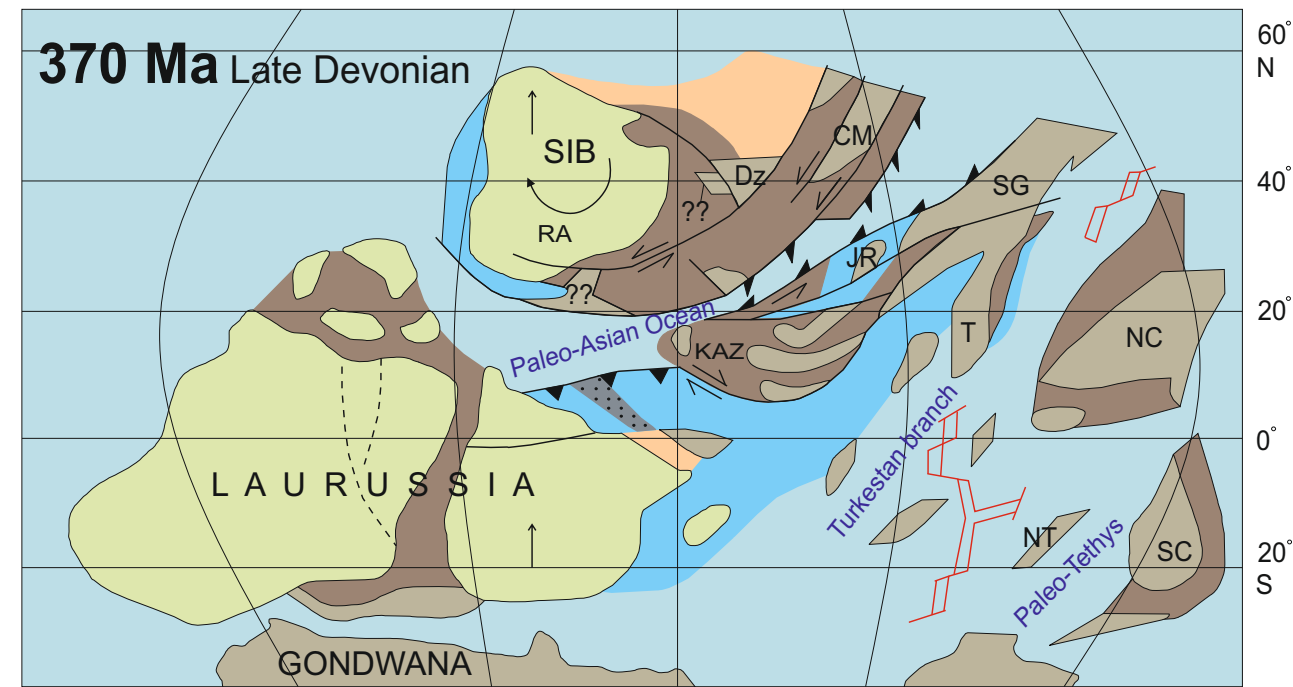




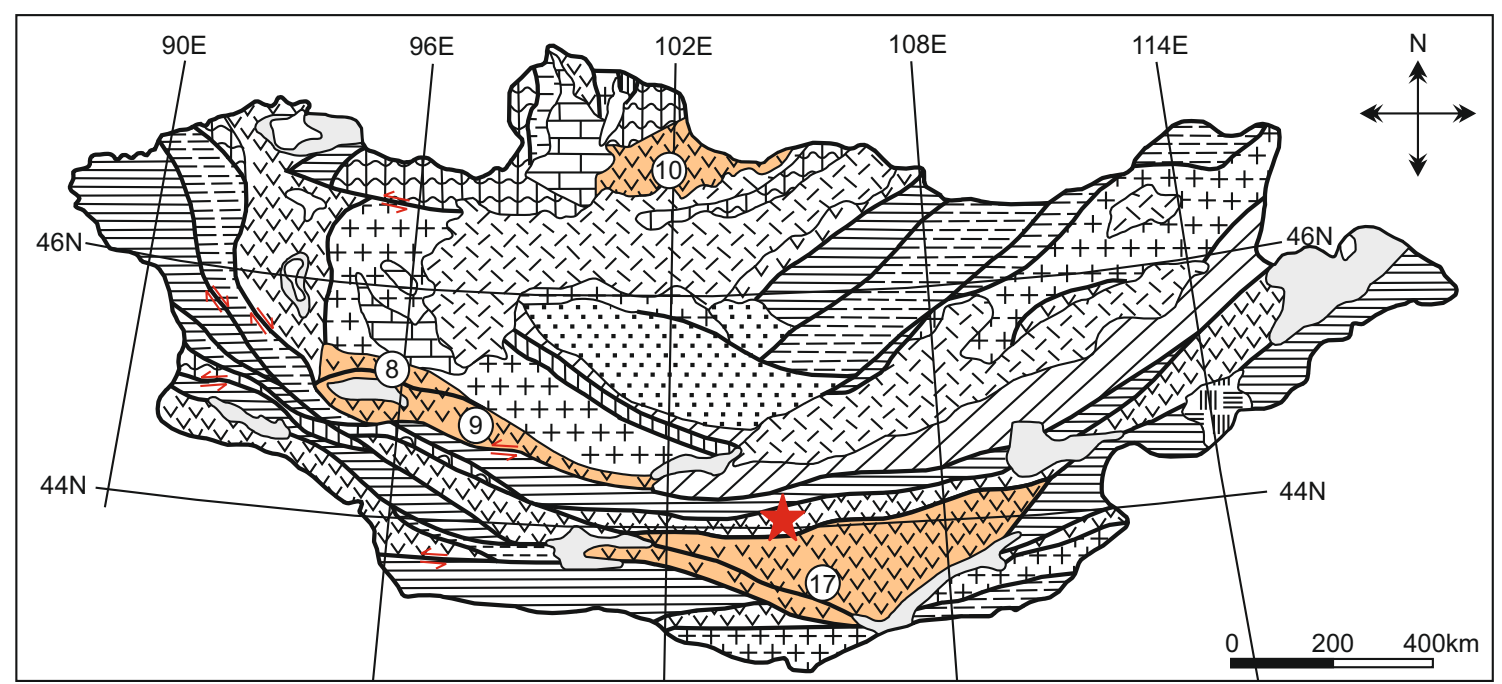

\begin{tabular}{|c|c|c|c|c|c|}
\hline & Cenozoic alluvial basin & \begin{tabular}{|l|l|}
\multicolumn{1}{|l|}{} & \\
\end{tabular} & $\begin{array}{l}\text { Cambrian shelf } \\
\text { carbonate rocks }\end{array}$ & Vvvv Island arc & Ophiolite \\
\hline 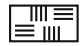 & Cenozoic plateau basalt & + & Microcontinent & Intra-oceanic arc & Right-lateral strike-slip faults \\
\hline 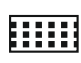 & $\begin{array}{l}\text { Devonian-Carboniferous } \\
\text { turbidite basin }\end{array}$ & Wक & $\begin{array}{l}\text { Metamorphic rocks of } \\
\text { uncertain tectonic affinity }\end{array}$ & Backarc/forearc basin & Left-lateral strike-slip faults \\
\hline 公 & $\begin{array}{l}\text { Permian-Triassic } \\
\text { volcanic-plutonic belt }\end{array}$ & & Passive continental margin & 巨三三ヨ Accretionary wedge & Faults; kinematics uncertain \\
\hline
\end{tabular}

Fig. 3 Main terranes of Mongolia (modified after Badarch et al. 2002), published in Safonova et al. (2017). The numbers in circles indicate intra-oceanic arcs and their hosting terranes: 8, Dariv; 9, Khan-Taishirin; 10, Dzhida; and 17, Gurvansayhan-Zoolen terranes

suggest a forearc setting. The volcanic rocks from adjacent terranes (Gobi Altai) also have high initial $\varepsilon N d$ values $(+6$ to +10$)$ and exhibit calc-alkaline, LREE-enriched island arc as well as tholeiitic LREE-depleted back-arc basin signatures of predominantly juvenile composition (Helo et al. 2006). The formation of the Gurvansayhan and Zoolen arc terranes is attributed to the evolution on the South Mongolian branch of the Palaeo-Asian Ocean (Zonenshain et al. 1975; Dobretsov et al. 1995; Buslov et al. 2001).

\section{Material and methods}

Most units which contain sediments were measured bed by bed at centimeter scale. A large number of rock samples were taken for microfacies analysis, geochemical analysis, and biostratigraphy. For the report presented herein, biostratigraphy is mainly based on conodonts (including collection data reported from that area) and radiolarians. Fifty-one conodont samples of approximately $2-4 \mathrm{~kg}$ each were taken from calcareous rock and limestone and processed by standard methods (see Jeppson and Anehus 1995). This process was repeated until samples were dissolved. Washed residues were dried in an oven and later sieved and separated into three fractions. Overall, conodonts are scarce and not well preserved and very often lack age-diagnostic species except those conodonts found in pure limestone in the Mississippian.In addition, we carefully examined previously published collections stored in
Mongolia. As a result of new biostratigraphic data and revision of previous conodont collections, we can improve the biostratigraphy of the Bayankhoshuu Ruins section. Conodont zonation schemes follow Lane et al. (1980), Corriga et al. (2009), Hartenfels (2011), and Spalletta et al. (2017). As it is common practice in conodont studies, only $\mathrm{Pa}$ elements were identified. Chert samples were processed but yielded few radiolarian species. All conodont and radiolarian samples will be stored at the Mongolian University of Sciences and Technology, Ulaanbaatar, Mongolia, under repository numbers (MUST-RCSP-CON-0041 to CON-0064 MUST-RCSP-RAD-0001 to RAD-0013).

Because the primary objective of the fieldwork was to characterize the sedimentary sequence in more detail than previously reported (Minjin et al. 2001, Wang et al. 2003a, b, 2005), sampling of the Minjin Member was undertaken as an ancillary part of the fieldwork. Facies and microfacies types (FT) were mainly compared on the basis of the classical models provided by Wilson (1975) and Flügel (2004); the description of siliciclastic rock follows the classification published in Folk (1954), Pettijohn et al. (1973), and Tucker (2001). For this overview, 57 thin sections of $7.5 \times 11 \mathrm{~cm}$ in size were used. Thin sections are stored at Senckenberg Research Institute and Natural History Museum Frankfurt, Germany, under repository numbers (SMF 99332-SMF 99391). All samples were taken along detailed measured sections and were incorporated into the lithological logs presented herein. Some sections 
represent compiled sections, and samples were taken where visual differences in composition or texture could be observed. GPS readings $( \pm 3 \mathrm{~m})$ record each sample location.

\section{Results}

Regional geology—Bayankhoshuu Ruins area

The different formations of the Bayankhoshuu Ruins section are briefly described in stratigraphical order from the oldest to youngest successions based on published data (Guidebook for the 2001 joint meeting of IGCP 410 and 421, Minjin et al. 2001; Wang et al. 2003a, b, 2005) and on new data obtained during fieldwork in 2019. In Fig. 4, we present a geological map of the area, which is based on published data (Minjin et al. 2001; Wang et al. 2005) and data that resulted from this study. We focused on Ordovician/Silurian, Middle to Late Devonian, and Mississippian rocks in order to get a better understanding of the complex relationships between the sedimentary and volcanic sequences as well as on events in the Palaeozoic of Mongolia. Biostratigraphy is mainly based on conodonts and some radiolarians, which generally support conodont data.

The color alteration of conodonts (CAI; Epstein et al. 1977) is high in most samples and ranges from CAI 4.5 to CAI 6. Conodonts found in the Mississippian exhibit lower CAI values, around CAI 3.5 to 4.0. Most samples are barren but conodonts were found in a limited number of samples. Many conodonts are fractured and incomplete. Due to the facies setting and diagenesis (silicification, recrystallization), processed samples yielded large volumes of residue.

The location of the sections we investigated in detail are shown in Fig. 4. Most strata are intensively folded and faulted. We have sampled three sections (A to C; see Fig. 4), ranging from the Late Ordovician to Silurian (Fig. 5) along a road west of the Olon Ovoot gold mine and a cross section near the Bayankhoshuu Ruins (Middle Devonian to Early Carboniferous) further in the north (Fig. 4). The latter one is subdivided into different sections which are characterized by a mixture of sedimentary rocks, volcanic rocks (basalts, pillow basalts, ?andesites, felsic volcanics), and volcaniclastic rocks (bentonites). The overall lithology of the rocks indicates some sort of island arc setting rather than a passive margin setting. Geographically, the locality is south of the Main Mongolian Lineament by $100 \mathrm{~km}$. The section is not consistent with deposition on the Idermeg Terrane or the Gobi Altai Terrane. Deposition likely occurred on either the Mandalovoo or Gurvansayhan Terrane. The geographic location of the field area is on the terrane boundary as drawn by Badarch (2002). Both terranes have similar origins.
Khoyormod Formation

The Khoyormod Formation outcrops $400 \mathrm{~m}$ west from the Bayankhoshuu Ruins (Fig. 4) and downhill from outcrops of Upper Jurassic volcanic rocks and was first described by Minjin (2001). The reported thickness of this member is about $400 \mathrm{~m}$, but our measured section of the formation only records a few tens of meters (Fig. 5), perhaps the result of thrusting. Parts of the Khoyormod Formation are exposed west of the field camp in section A (Fig. 5). This formation is represented by an alternation of gray, greenish-gray mudstone, sandstone with limestone lenses, and some fossiliferous limestone. These limestones contain crinoids and corals such as Karagemia altaica and Khangailites hetermorphosus. The fauna is widely distributed in Upper Ordovician carbonate facies in Mongolia.

A number of limestone samples were taken for conodont biostratigraphy (Fig. 5), but all samples were barren except sample BR-C-2. Conodont fauna from the Late Ordovician Khoyormod Formation did not yield diagnostic conodonts of the Amorphognathus ordovicicus biozone, which is attributed to the Ordovician Extinction Event (Hirnantian) but yielded one conodont element of Walliserodus $\mathrm{cf}$. amplissimus or Hamarodus sp. The predominance of Walliserodus amplissimus species represents a characteristic species which occurs in the Hirnantian in Europe (e.g., Ferretti and Serpagli 1999; Rodriguez-Canero et al. 2010). Sediments are characterized by an alternation of crinoidal grainstone, echinoderm packstone, wackestone, and floatstone (Fig. 6ad; Fig. 7a, b). Crinoidal grainstone layer can reach a remarkable thickness of several decimeters to meters. The entire section is fractured from millimeter to decimeter size and is characterized by rocks which underwent strong tectonic strain and overburden which resulted in solution seams and brecciated fabric (Fig. 6a-c). It is interesting to note that facies change occurs in the middle part of the sampled Khoyormod Formation. Gray limestones with iron-stained micritic matrix with hematite nodules conformably overlay micritic limestone and crinoidal grainstone (Figs. 5 and $6 \mathrm{~d}$ ).

\section{Mandalovoo Formation}

Gavuu Member: The Gavuu Member comprises micritic limestone (up to $100 \mathrm{~m}$ thick), nodular limestone, and intercalations of thin-bedded siltstone. The limestone yielded corals such as Favosites gothlandicus, F. kennihoensis minus, and Catenipora minuta indicating a Llandoverian age (Minjin et al. 2001). Other fauna, such as conodonts (e.g. Ozarkodina inclinata inclinata) are reported from the same authors.

In our section the Gavuu Member is represented by a reduced sedimentologic record and exhibits mainly massflow deposits in section "B" which are covered by thin-bedded siltstone, sandstone, crinoidal grainstone, and basalt (Fig. 5). 


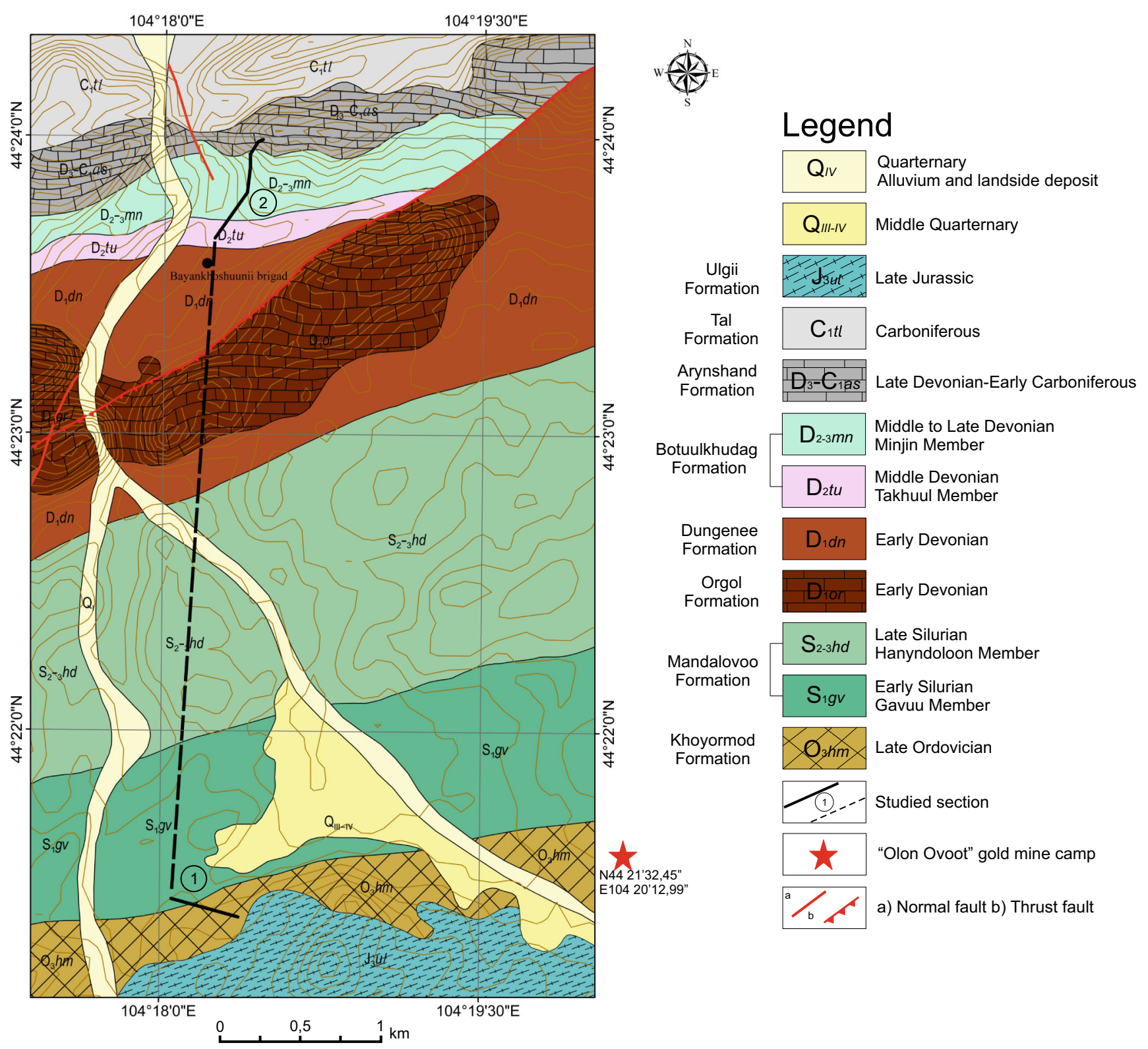

Fig. 4 Geological map of the working area (Mushgai, southern Mongolian Gobi, Umnugobi Province, Mandalovoo area) and the sections investigated (the stippled line represents those parts of the section we have summarized). Study area \#1 is composed of three sections (hills A-C, Ordovician to Silurian rocks; see lithological log Fig. 5); area \#2 is composed of three sections (Lower Devonian to Mississippian rocks; see lithological logs Figs. 8, 11, and 12)

range from Llandovery to early Wenlock for the Gavuu Member. The stratigraphical range of the conodont species Kockella ranuliformis is important in terms of events in the Late Palaeozoic insofar as the Ireviken Event (late Telchian-Sheinwoodian) coincides with a profound change in the pattern of sedimentation, from the shale-dominated units of the Pterospathodus amorphognathoides conodont biozone worldwide to the pure carbonates of the overlying Kockelella ranuliformis biozone, which has been interpreted to reflect the largest-magnitude eustatic event of the entire Silurian (Johnson 1996; Barrick 1997; Salzmann 2001; Zhang et al. 2017). This lithologic change has been interpreted The fauna from the Mushgai area suggests a stratigraphical 


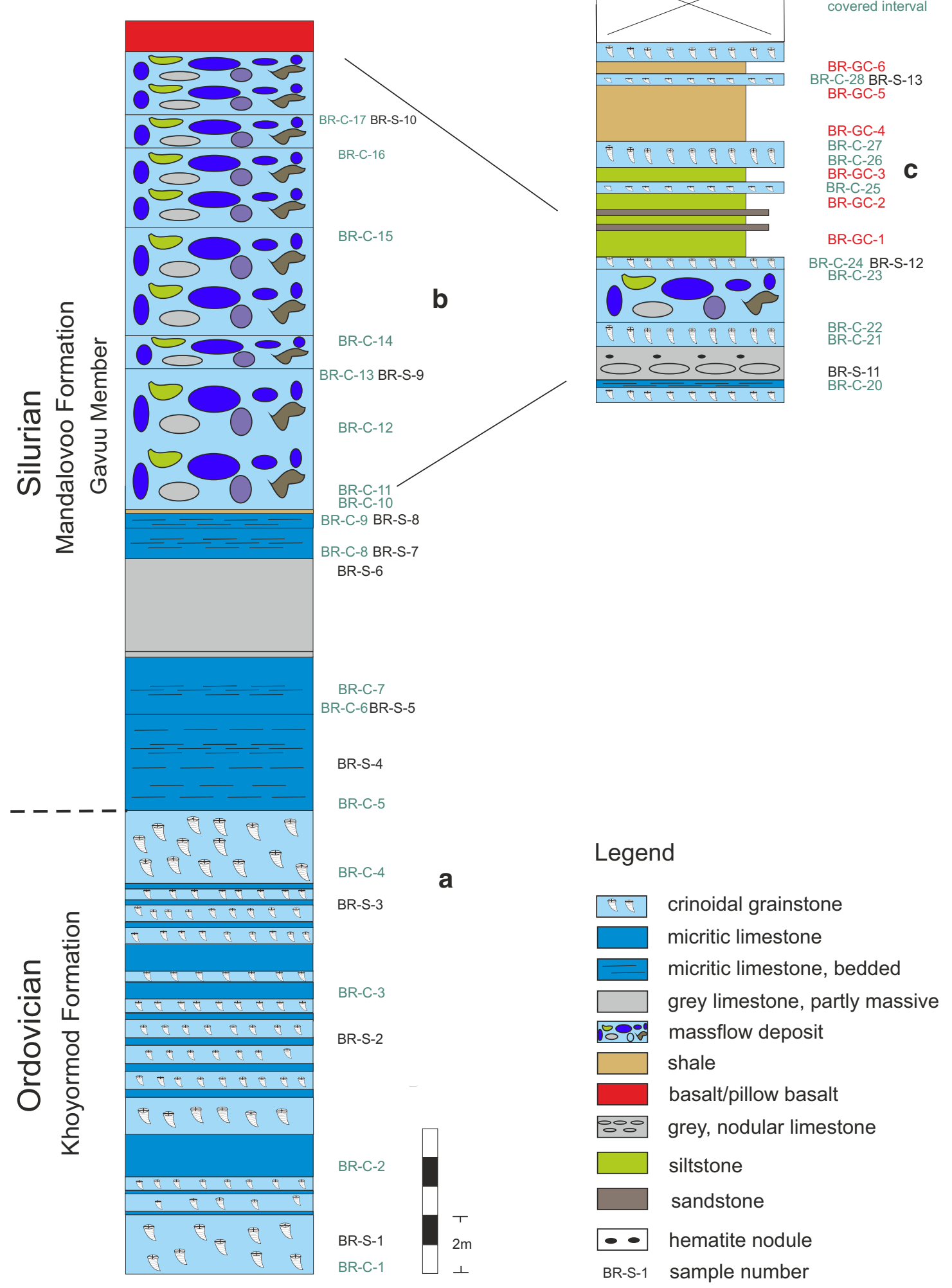

Fig. 5 Compiled lithological log of three hills (sections A to C, \#1 in Fig. 4) along the road west of the Olon Ovoot gold mine (Khoyormod Formation, Ordovician; Mandalovoo Formation, Gavuu Member,

Silurian), Bayankhoshuu Ruins area, Umnugobi Province. Sample numbers: "C" = conodont samples, "S" = sedimentology/facies, "GC" = samples for geochemistry 

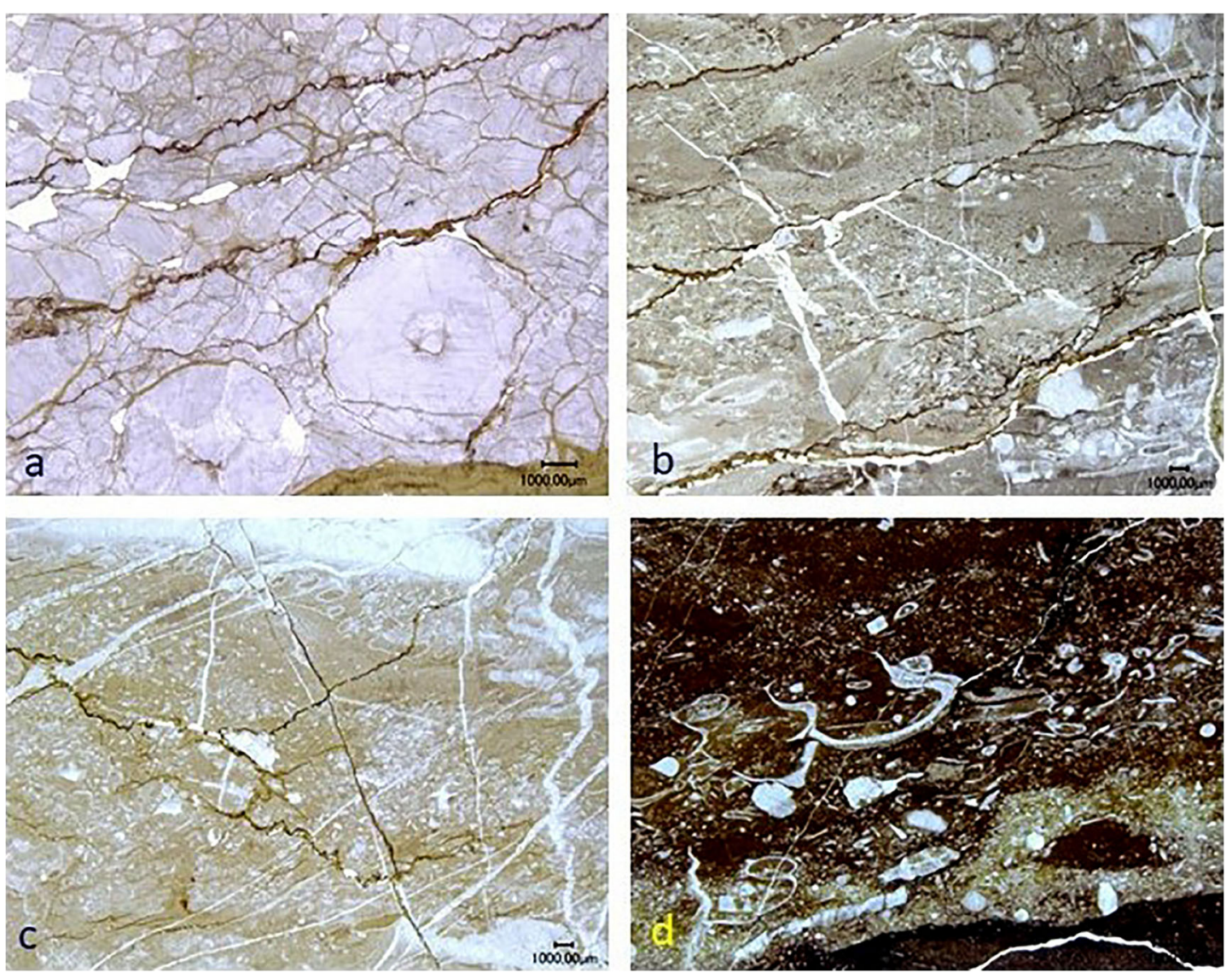

Fig. 6 Microfacies of the Khoyormod Formation; a echinoderm packstone shows a condensed fabric. The parallel set of stylolites originates from selected pressure solution. The components produce a puzzle-like fabric and are surrounded by solution seams (sample BR-S1); b fossiliferous micritic limestone with irregular anastomosing set of stylolites underlain by a fossiliferous limestone with corals and

echinoderms (sample BR-S-5); $\mathbf{c}$ fossiliferous wackestone with micritic matrix. The sediment is slightly burrowed and shows an irregular anastomosing set of stylolites (sample BR-S-6); d floatstone with large bioclasts (e.g., trilobites, echinoderms, brachiopods), small shell hash, and rare corals and bivalves. The iron-stained matrix is clayey to micritic (sample BR-S-4)

as the largest worldwide regression of the Silurian (Johnson 1996; Barrick 1997). Johnson (2006) pointed out that the Ireviken Event took place during the whole regression which is supported by a hiatus and a sequence boundary reported from East Baltic area by Nestor et al. (2002) and Loydell et al. (2003). In our section, this transition may correlate with the transition from micritic limestones to mass-flow deposits (Fig. 5), but the diagnostic conodonts such as Kockella ranuliformis have not been found in this section so far. Further studies on detailed stratigraphy and geochemical analysis are necessary (work in progress) to confirm the biostratigraphic results by Vorozhbitov (1997).

Hanyndoloon Member: The folded sediments of this member were described in the 2001 IGCP field guidebook from the area (Minjin et al. 2001). The transition from the calcareous sediments to more siliciclastic sediments may be exposed in the small section \# 1C (Figs. 4 and 5), but the transition to the overlying greywacke is not exposed in the studied section.
Greywacke beds can reach thicknesses of several meters and exhibit characteristic sedimentological features such as graded bedding, load casts, and flute casts (Fig. 7c). The Hanyndoloon Member is composed of green mudstone, sandstone, and greywacke, the latter having a thickness of about $600 \mathrm{~m}$. The lower and upper contacts of this formation are not exposed and are believed to be of tectonic origin (Minjin et al. 2001). According to Minjin et al. (2001), the Hanyndoloon Member has a stratigraphical range from Ludlow to Pridoli. This part of the section was not sampled in detail (see stippled line in Fig. 4) and is not shown in the lithological logs.

\section{Orgol Formation}

The Orgol Formation was first described and named by Minjin et al. (1993). Wang et al. (2003a,b, 2005) preferred to use the name Olonovoot Formation based on new conodont findings in samples M-9 to M-12 (Wang et al. 2005) of the Bayankhoshuu Ruins section. The base of this formation is 

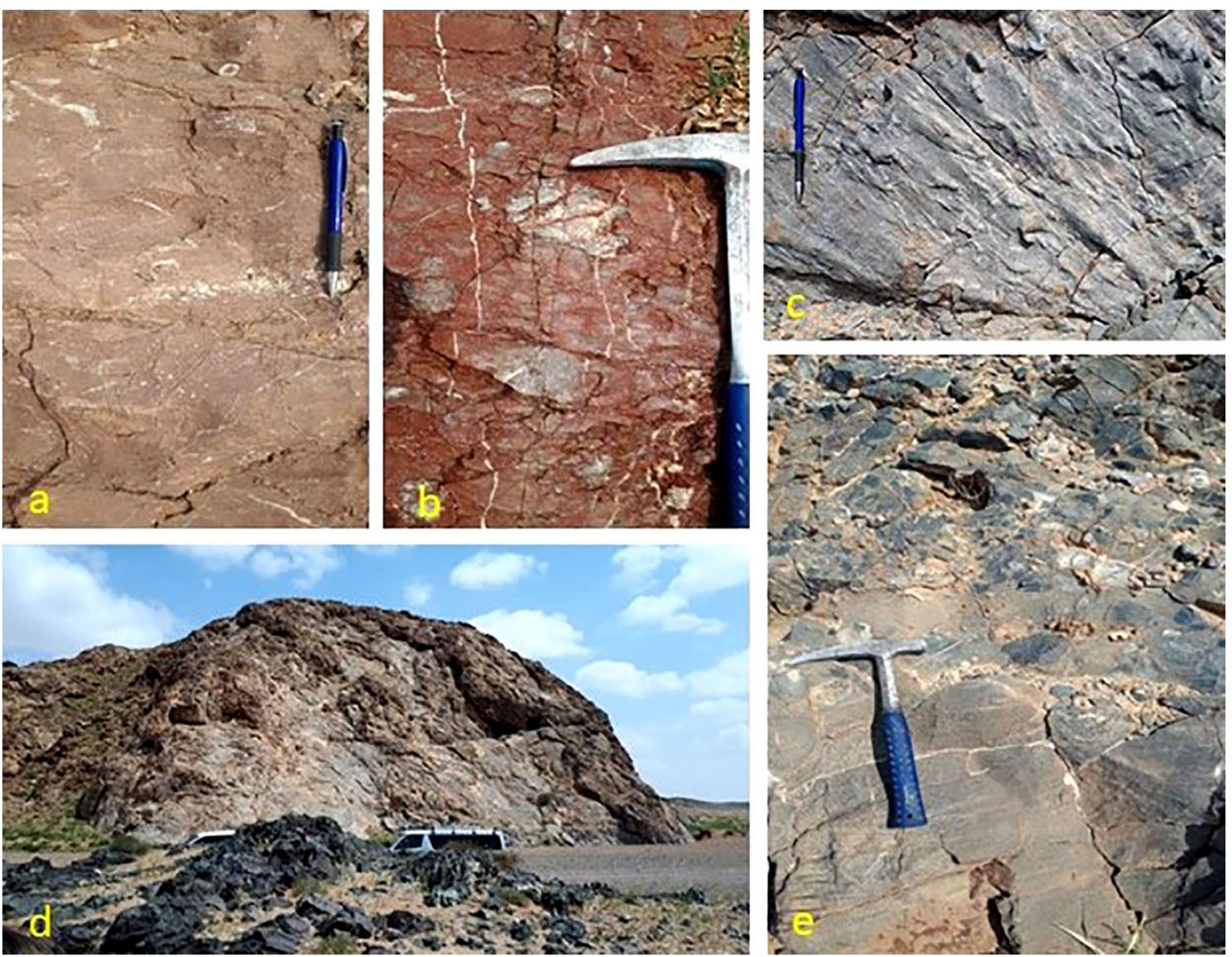

Fig. 7 Field photographs showing lithological units and sedimentological features observed in the Bayankhoshuu Ruins section, Mandalovoo Formation: a alternation of reddish crinoidal grainstone and micritic limestone of the Ordovician Khoyormod Formation (Bayankhoshuu Ruins area, Umnugobi Province; photo taken close to sample BR-S-2). b massflow deposits of the Gavuu Member with reworked corals (Mandalovoo Formation; photo taken from sample close to BR-S-7). c Greywacke with flute casts at the lower surface, Hanyndoloon Member
(Mandalovoo Formation, cross section near the Bayankhoshuu Ruins). d Bioherm of the Orgol Formation, cross section near the Bayankhoshuu Ruins, Umnugobi Province; the Dungenee Formation is shown here in front of the Orgol Formation. e Sandstone and conglomerate of the Takhuul Member, Botuulkhudag Formation (cross section near the Bayankhoshuu Ruins, Umnugobi Province; photo taken from the base of the section around sample BR-S-15) mainly composed of "conglomeratic limestone" which has a thickness of 70-100 m.

The stratigraphical range of this formation is still in discussion. Several spot samples with different fauna were taken along a cross section near the Bayankhoshuu Ruins (e.g., Wang et al. 2003a, b; Wang and Chuluun 2004), but the exact sample position in older publications remains uncertain in some cases as the authors took spot samples to get an idea on the stratigraphy; a detailed measured section was beyond their aim. However, tabulate and rugose corals reported from bioherms of the Orgol Formation such as Favosites socialis, Pachyfavosites subnitellus, P. gicinger, Thamnopora solida, Striatopora longa, Cladopora sp., Hellaeopora sp., Lecomptia sp., Caliopora sp., and rugosans such as Spongophylloides perfecta, and Spongophylum halysitoides indicated a Lochkovian age. Another spot sample comes from the lowermost limestone layer of the section sampled by Wang (see N $44^{\circ} 22^{\prime} 60^{\prime \prime}$, E $104^{\circ} 17^{\prime} 76^{\prime \prime}$, Wang et al. 2003a, b) which yielded the important conodont species Caudicriodus woschmidti which indicates also Lochkovian age. Similar results were reported by Minjin and Tumenbayar (2001). The Caudicriodus woschmidti (or $C$. hesperius) conodont biozone has been recognized as the lowermost unit of the Devonian, and its base as the Pridoli/Lochkovian boundary. Wang et al. (2003a,b) found the conodont Pandorinellina exigua which suggested an early Emsian age as the earliest occurrence of this species is from the base of the early Emsian (Murphy et al. 2004). The disadvantage of the identification by Wang et al. (2003a,b, Plate 1, Fig. 6) is that the authors did not figure the critical parts of the Pa elements that are necessary for identification, the basal views of the $\mathrm{Pa}$ elements. Thus, a stratigraphic range into the Emsian is questionable. From our point of view, the Orgol Formation is of Lochkovian in age which is overlain by the Pragian to Emsian Dungenee Formation. Whether the contact between both formations is conformable or whether it is a tectonic contact remains questionable. 


\section{Dungenee Formation}

The Dungenee Formation can be subdivided into two units. A lower unnamed sandstone unit is composed of sandstone and some grayish limestone layers (50 $\mathrm{m}$ thick). From the fossiliferous limestone, the following fossils are reported: brachiopods (Cymostrophia (?) sp.), tabulate corals (Favosites admirabilis, Caliopora sp., Coenites sp.), rugose corals (Pseudomicroplasma compositum), crinoids, bryozoans, and gastropods. The fauna indicates a Pragian to Emsian age. The thickness of this succession is about $400 \mathrm{~m}$ (Fig. 4).

The upper part of the Dungenee Formation is named the Murugtsug Member and is composed of dark-gray, greenishgray, gray, massive-bedded, and medium-thin-bedded fossiliferous limestones. The following fossils are reported (Minjin et al. 2001): crinoids such as Syndetocrinus natus, Pandocrinus pandus, Crotalocrinites cf. rugosus, brachiopod (Atrypa sp.), tabulate corals (Favosites admirabilis, Pachyfavosites preplacenta, P. subnitellus, P. gicinger, Plicatomorus giganteus, Gerphuropora multiplicata, Yacutiopora sp., Thamnopora diserta, T. solida, Coenites dunginensis, C. sp., Caliopora sp.), and rugose corals (Pseudomicroplasma compositum, Embolophyllum agregatum, Spongophylloides tomasae, S. dubrovensis, and Spongophyllum halysitoides).

\section{Botuulkhudag Formation}

The Botuulkhudag Formation (Fig. 8) is divided into the Takhuul and Minjin members. The Takhuul Member conformably overlies the Dungenee Formation (Fig. 8). The base is Eifelian in age whereas the upper boundary is not well defined (Wang et al. 2005). The total thickness of the Botuulkhudag Formation is $610 \mathrm{~m}$.

Takhuul member: The Takhuul Member (Figs. 8 and 9a-h) in our section starts with siltstone overlain by a fine- to mediumgrained arkosic sandstone which is composed of quartz, feldspar, and some lithic clasts (Fig. 9a).

The clasts contain less than $10 \%$ of matrix. Quartz grains and lithoclasts are angular to subangular and the sediment is moderately sorted. The majority of the Takhuul Member is composed of a polymict conglomerate with fine rounded pebbles and boulders (ranging from 5 to $40 \mathrm{~cm}$ in diameter, Figs. 7e and 9b); coarse- to fine-grained, gray to brownish calcareous sandstone; sandstone with sandstone pebble; reddish to brownish siltstone; and limestone. Limestone boulders often contain excellently preserved Early Devonian corals (Fig. 9b; Minjin et al. 2001) and may represent reworked material from the Orgol Formation. Occasionally, corals are overgrown by stromatoporoids (Fig. 9b). Due to strong recrystallization, species-level classification of the stromatoporoids is poorly constrained.

These fossiliferous wackestones (Fig. 9d-f) represent the majority of the boulders. Overall, the polymict conglomerate is composed of well-rounded sedimentary rocks of various sizes. Interestingly, the matrix itself is a polymict conglomerate as well (Fig. 9c) containing angular to well-rounded clasts of sandstone, siltstone, and limestone. The conglomerate covers a large area and has a thickness of $30 \mathrm{~m}$ (Fig. 8). The coarsening upward (siltstone-sandstone-conglomerate) sequence at the base of the Takhuul Member requires a high-energy environment. Deposition of conglomerates occurred most probably along a beach with strong waves. Furthermore, sedimentological analysis (size of samples, composition, and age) suggest an environment with a certain morphology/rapid uplift (cobble-size rocks) and/or sea-level changes of an appropriate magnitude. Whether this succession was linked with tectonic events (e.g., amalgamation of terranes) requires more detailed studies on other sections. The transition to micritic limestones at the top of this formation is not exposed (Fig. 8). Micritic limestones are covered by a thin-bedded calcareous sandstone with angular to rounded clasts (Fig. 9g). This succession is overlain by a black shale followed by limestones, shale, and a sandstone at the top of the Takhuul Member (Figs. 8 and 9h). According to Minjin et al. (2001), the Takhuul Member is of Eifelian in age. The earliest Eifelian was a time of relatively high eustatic sea-level (middle part of T-R cycle Ic sensu Johnson et al. (1985), Johnson and Sandberg (1989), and Walliser (1996)) related to the transgressive "Basal Chotec Event" (see Chlupac and Kukal 1986). Whereas the basal part of our section represents an overall shallow-water succession (coarsening-upward sequence), the transition from micritic limestone to a black shale represents deeper water environment, which might be associated with the "Basal Chotec Event." At the time of writing this report, this is a hypothesis based on the remarkable lithological shift that requires more detailed stratigraphical and geochemical studies (work in progress). The Takhuul Member is conformably overlain by the Minjin Member. The transition to the next younger member was placed above a thick-bedded quarzitic sandstone with the first bentonite bed of this section (Fig. 8).

Minjin member: According to earlier descriptions (e.g., Minjin et al. 2001, Wang et al. 2005), the Minjin Member (Figs. 10, 11, and 12) is subdivided into two parts. The lower part is composed of dark-green tuff and lava with dark-gray lenticular limestones and is assigned to Givetian (Minjin et al. 2001). The middle and the upper parts of the Minjin Member are not composed of shale and sandstone as described in the guidebook (Minjin et al. 2001), but are siliceous mudstone, siltstone, and chert. The Minjin Member of the Botuulkhudag Formation is primarily a basaltic sequence with minor sediments except in the middle part of the section (Fig. 11) where radiolarian chert and siltstone occur. The Minjin Member in our section begins with an alternation of shale and bentonite. The latter can reach a remarkable thickness of several meters. 


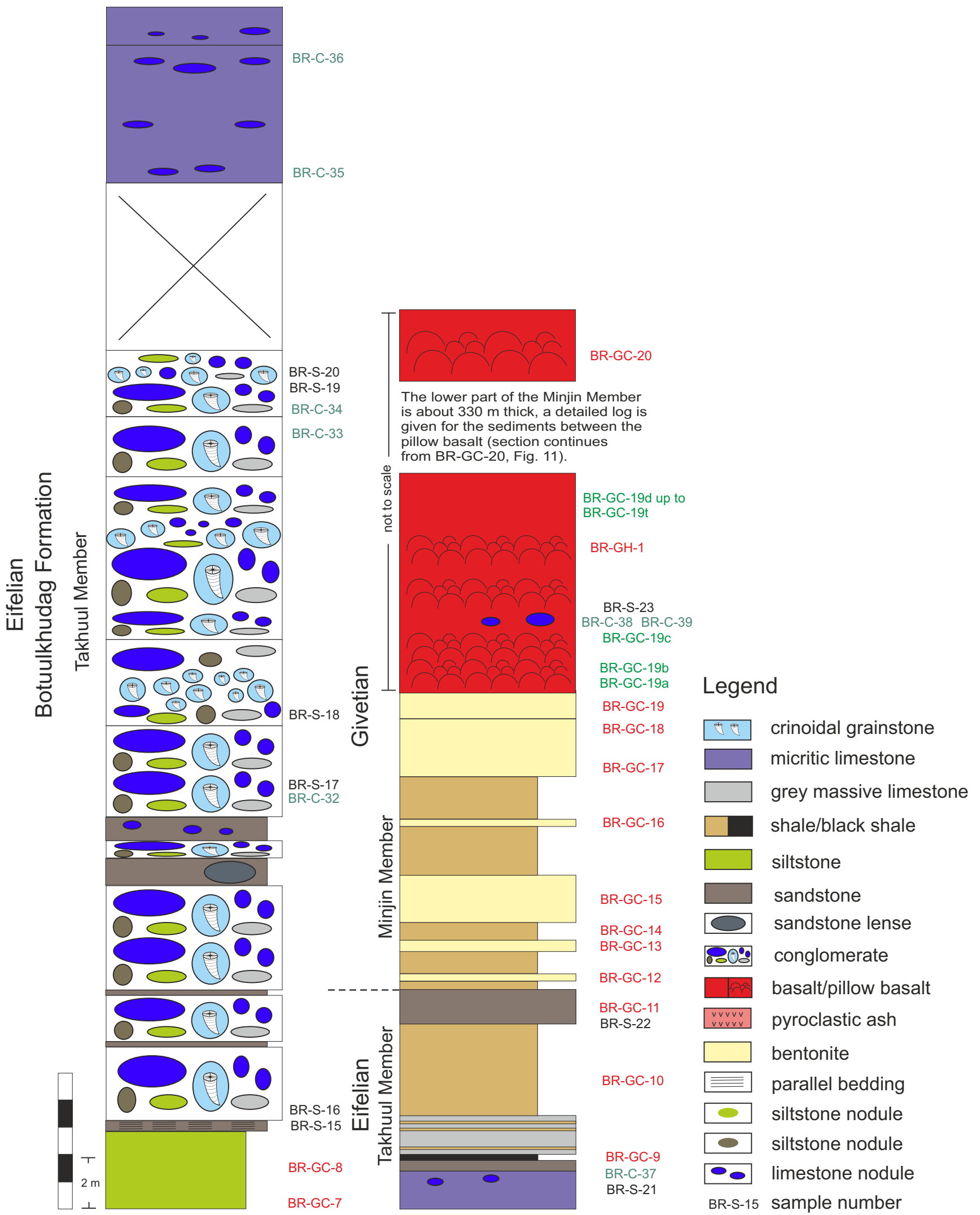

Fig. 8 Lithological log of the Botuulkhudag Formation, Takhuul Member, and the lower part of the Minjin Member (cross section near the Bayankhoshuu Ruins, Umnugobi Province). Base of the section: N $44^{\circ} 23^{\prime} 39.5^{\prime \prime}, \mathrm{E} 104^{\circ} 18^{\prime} 14.2^{\prime \prime}$; end of the section: N 44 $23^{\prime} 41.0^{\prime \prime}, \mathrm{E}$ $104^{\circ} 18^{\prime} 13.6^{\prime \prime}$. Note that a detailed lithological log of the section within the basalts is shown in Fig. 11. Sample numbers: "C" = conodont samples, "S" = sedimentology/facies, "GC" = samples for geochemistry 

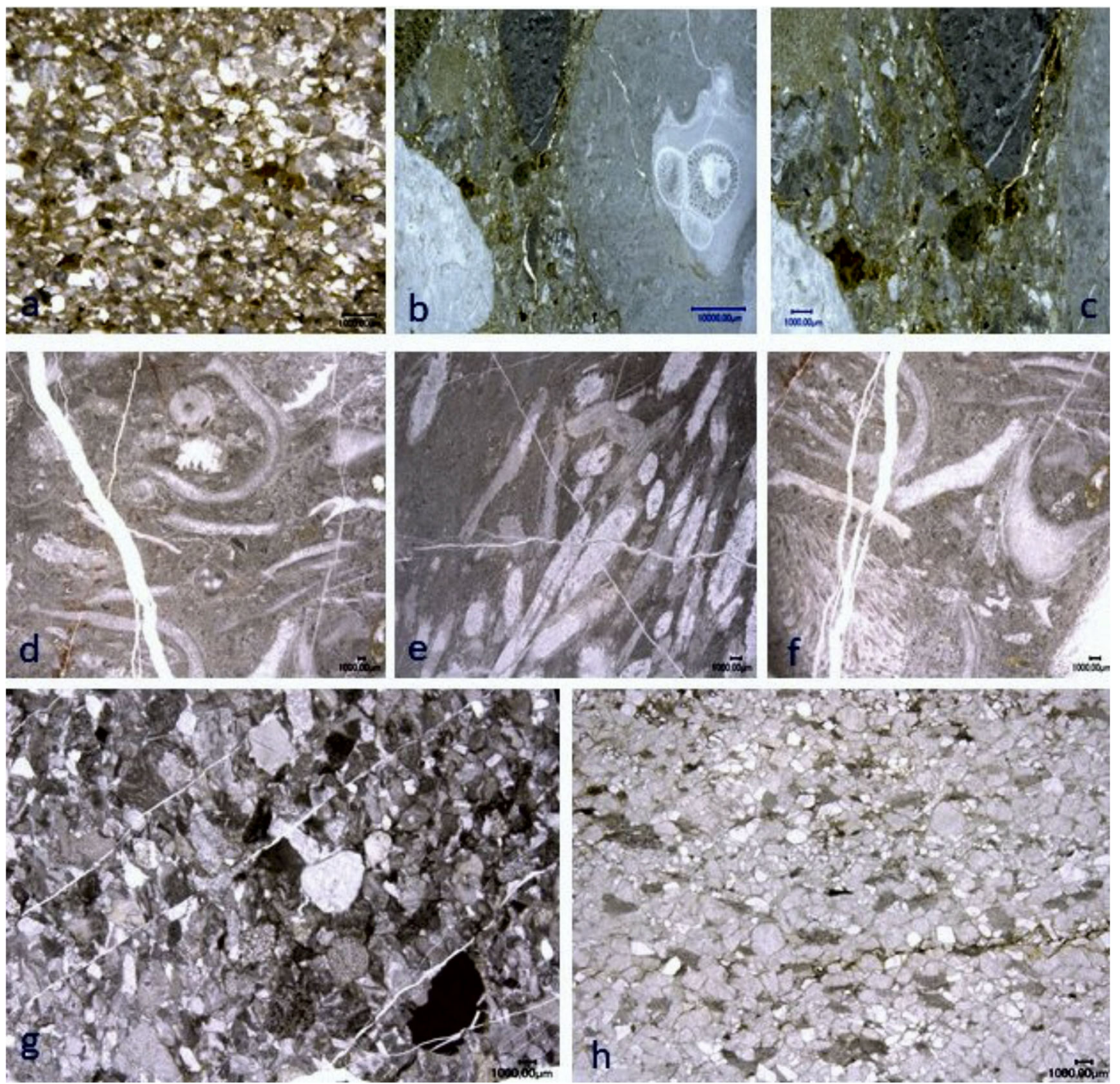

Fig. 9 Microfacies/lithology of the Botuulkhudag Formation, Takhuul Member; a Arkosic sandstone at the base of the Takhuul member (sample BR-S-15); b various clasts of the conglomerate; fossiliferous limestone clasts with excellent preserved corals; reworked material with geopedals (sample BR-S-18); c detailed view of the conglomerate matrix showing the sedimentary clasts with sand and smaller-sized particles filling the spaces between them. The largest pebbles are about $10 \mathrm{~mm}$

This section is covered by fine-grained basalt and pillow basalt. At the base of this succession, which has a thickness of approximately $330 \mathrm{~m}$, isolated micritic limestone boulders occur, which were sampled for conodonts but were barren. Thus, we refer to Minjin et al. (2001) who sampled the same limestone (sample BR-C-38 and BR-C39 in our section) and reported an early Givetian age of that part of the section.

Within the thick basalt succession (see Fig. 8), we have sampled a section in detail (Fig. 11) which is mainly composed of an alternating sequence of siliceous mudstone, siltstone, chert, and volcaniclastic rock (Figs. 8b-d, 9, and 11). The latter ones show components of magma as well as previously cemented rocks, such as cherts. Thin sections and hand across (sample BR-S-20); d-f fossiliferous wackestone to floatstone representing the carbonate boulder from the conglomerate (samples BRS-18, BR-S-20); note the diverse fauna such as corals, crinoids, and brachiopod shells; $g$ calcareous sandstone of the upper part of the Takhuul Member (sample BR-S-21); components are subangular to subrounded and the sediment contains extraclasts (shale); $\mathbf{h}$ moderately sorted thick-bedded sandstone at the top of the Takhuul Member

samples exhibit normal and inverse gradation (Fig. 10d). This succession is covered by large pillow basalts (Fig. 10e) which reach diameters larger than $2 \mathrm{~m}$. This continuous succession (see \#2 of Fig. 4) ranges from the Givetian to ?early Frasnian based on conodonts and radiolarians found in the underlying and overlying sediments.

The overlying unit (Fig. 12) is composed of shale, pyroclastic rock and silicified siltstone and chert. Pyroclastic rocks, which can reach a thickness of several meters, provide evidence of strong subaerial volcanism in the Late Devonian.

Based on field observations and laboratory analysis, radiolarians are found in this part of the section in samples BR-F-3 to BR-F-6 (Fig. 12). The radiolarian assemblage (Fig. 13a-m) 

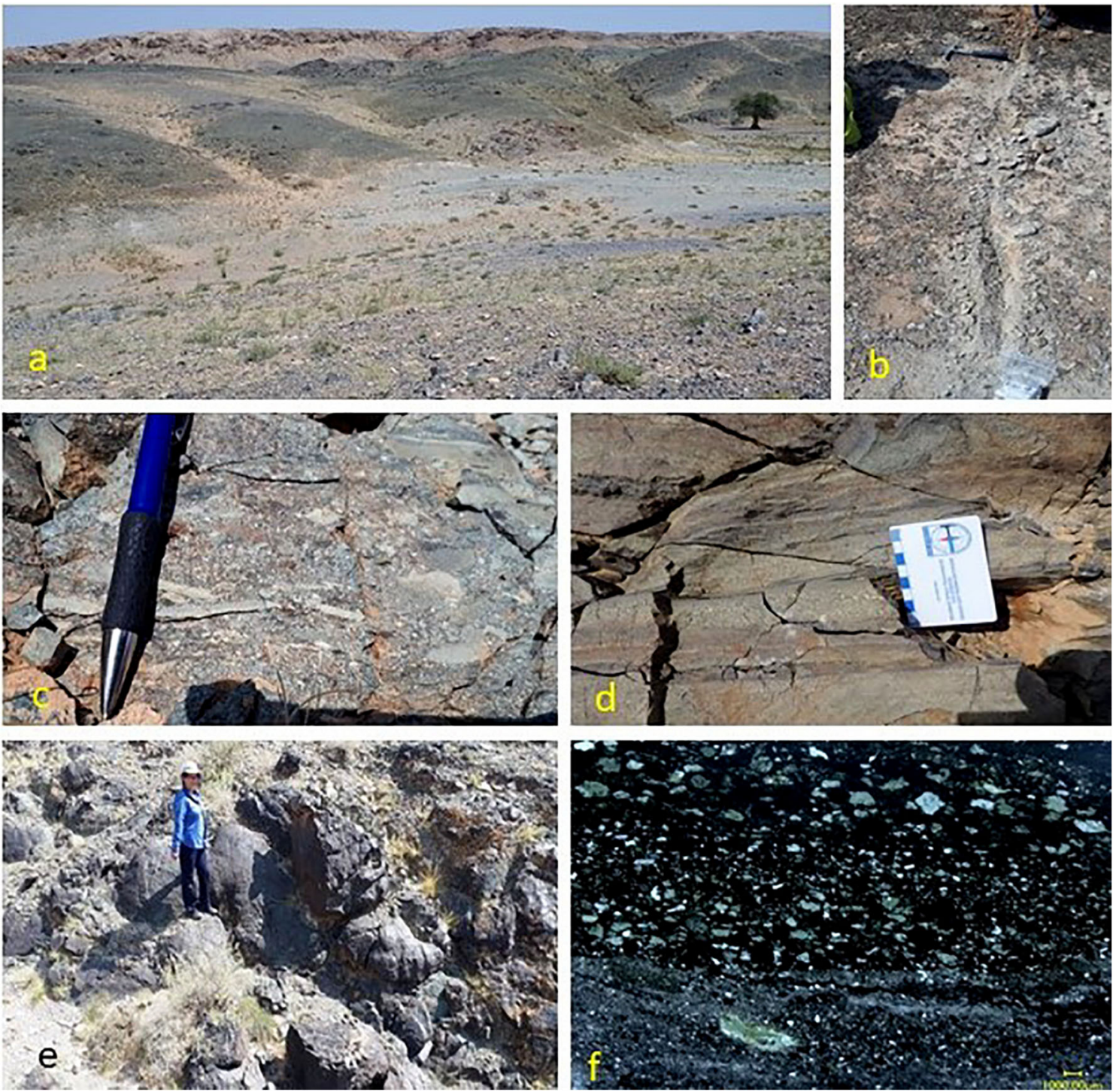

Fig. 10 Field photographs (a-e) showing lithological units and sedimentological features of the Minjin Member, Bayankhoshuu Ruins section; a overview of the micritic limestone (blueish color) shales and bentonite (grayish and whitish rocks) which are covered by basalts (brownish color), view to the North; Botuulkhudag Formation, Minjin Member (cross section near the Bayankhoshuu Ruins, Umnugobi Province); b detail of thick-bedded bentonite (sample BR-CG 17), Botuulkhudag Formation, Minjin Member (cross section near the Bayankhoshuu Ruins, Umnugobi Province); c detail of pyroclastic rock (sample BR-GC 40; see Fig. 10), Botuulkhudag Formation, Minjin

is not very diverse and poorly preserved as a result of metamorphism (recrystallization) but points to a Late Devonian age.

Representatives of the genus Stigmosphaerostylus (not figured herein) found in samples BR-F-3 and BR-F-4 are not helpful biostratigraphically as this genus has a long stratigraphical range from the Early through Late Devonian. Trilonche minax (Fig. 131, m; sample BR-F-6) is part of the Trilonche minax assemblage and ranges from the uppermost Givetian to lower Frasnian as reported from the Gamilaroi
Member (cross section near the Bayankhoshuu Ruins) generated by explosive fragmentation of magma and/or previously solid rock during the course of volcanic eruptions; $\mathbf{d}$ detail of pyroclastic rock with inverse gradation (sample BR-S-43; see Fig. 10), Botuulkhudag Formation, Minjin Member (cross section near the Bayankhoshuu Ruins, Umnugobi Province) which exhibits inverse gradation; e large pillows in the upper part of the Minjin Member, Botuulkhudag Formation (cross section near the Bayankhoshuu Ruins, Umnugobi Province); $f$ thin section of a pyroclastic rock with inverse gradation, Minjin Member (sample BR-S-43; see Fig. 11)

Terrane in the New England Orogen, Eastern Australia (Aitchison et al. 1999, 2017). In Thailand and Laos, this species is found in Frasnian sections (Thassanapak et al. 2012; Wonganan and Caridroit 2005). However, this species is also known from Givetian as well as from Frasnian and Famennian sections in Russia, China, and the USA (Foreman 1963; Nazarov 1975; Wang et al. 2003a,b). Helenifore robustum (Fig. 13d-k; sample BR-F-3) occurs in late Frasnian worldwide (e.g., Wang et al. 2003a,b). The radiolarian stratigraphy is supported by conodonts found in samples BR-F-4 and 


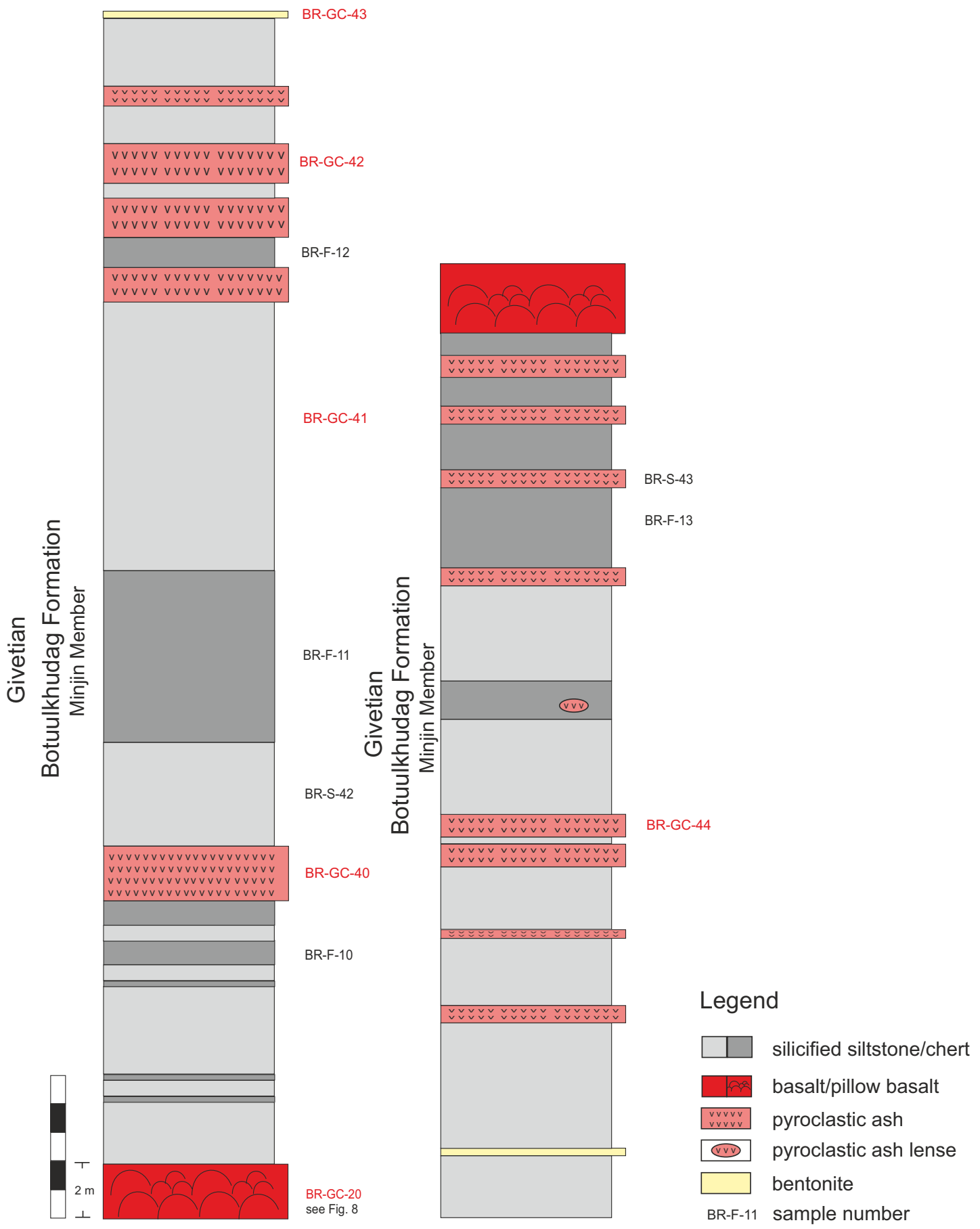

Fig. 11 Lithological log of the Botuulkhudag Formation, Minjin Member (detailed section in between pillow basalts; see Fig. 8; Bayankhoshuu Ruins section, Umnugobi Province). Base of the section: N $44^{\circ} 23^{\prime}$

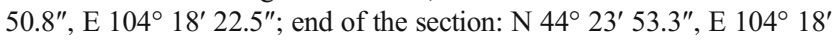

sample BR-F-5 (see Figs. 12 and 13). The conodont species Polygnathus angustidiscus (Fig. 13p, q; sample BR-F-4) and Polygnathus pollocki (Fig. 13n, o; sample BR-F-5; Fig. 12) range from the Middle Devonian (Givetian) to the Late Devonian (Frasnian) (e.g., Narkiewicz and Bultynck 2016). $24.8^{\prime \prime}$. The basalt at the top corresponds with the basalt at the base shown in Fig. 12. Sample numbers: "F" = fauna samples, "S"= sedimentology/ facies, "GC" = samples for geochemistry

Polygnathus pollocki has been reported in many studies from Upper Devonian rocks such as from Poland by Balinski (1979) and Racki (1992) ranging from the transitans to the punctata conodont biozone (late Frasnian to middle Frasnian), and from the Canning Basin, Australia, where this species 


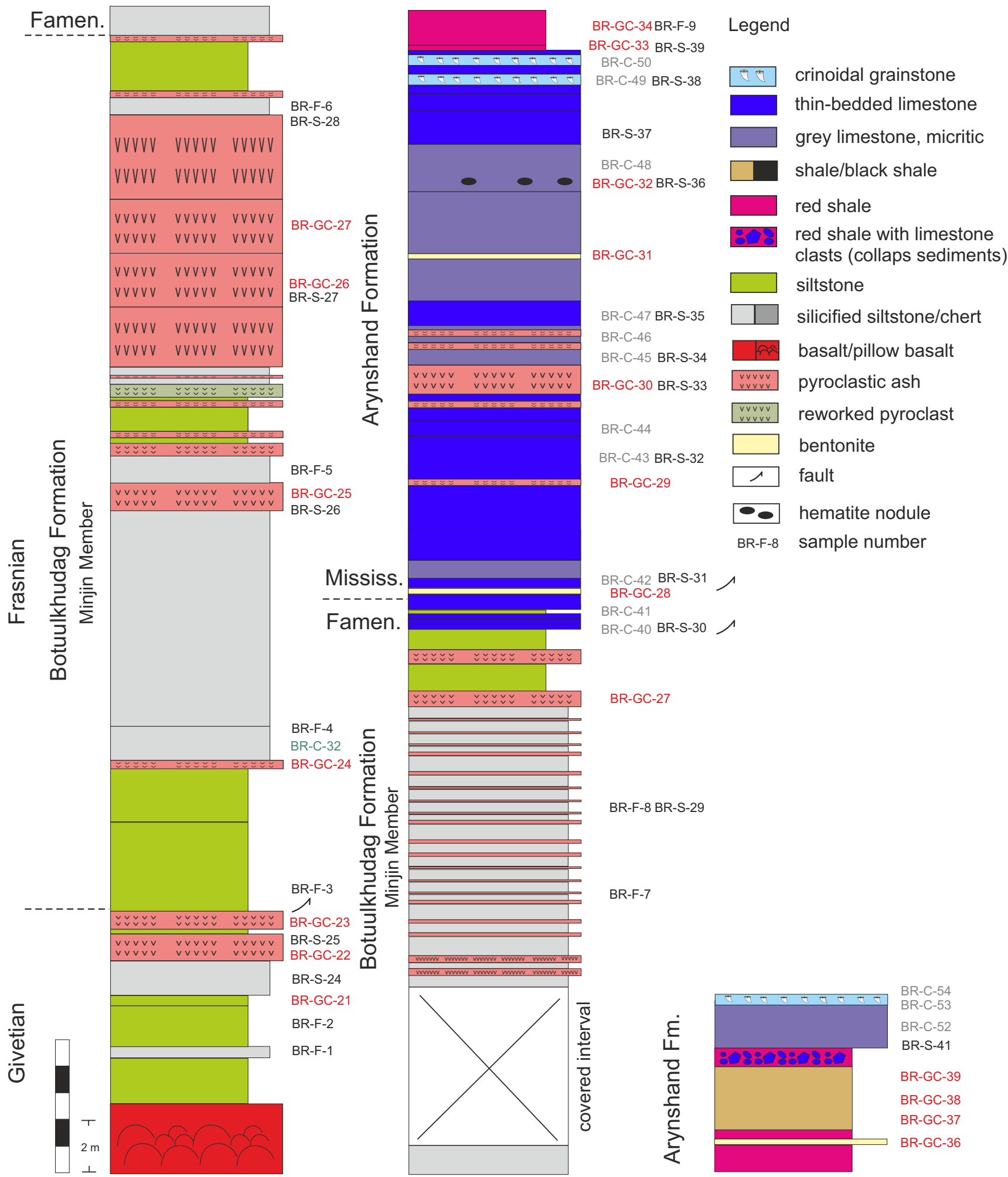

Fig. 12 Lithological $\log$ of the Botuulkhudag Formation (Minjin Member) and the Arynshand Formation. Base of the section: N 44 $23^{\prime}$

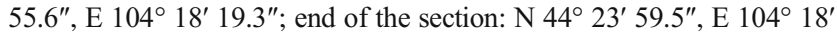

ranges into the early Famennian (Druce 1976). Along with the radiolarian data, this part (BR-F-3 to BR-F-6) of the Minjin Member suggests a late Frasnian age.
27.5". Sample numbers: "C" = conodont samples, "F" = fauna samples, "S" = sedimentology/facies, "GC" = samples for geochemistry

This succession is conformably overlain by the uppermost part of the Minjin Member which is characterized by an alternation of silicified siltstone, chert, and thin-bedded pyroclastic rock 
(Fig. 11). Unfortunately, we do not have any radiolarian data from this part of the formation. Both samples (BR-F-7 and BRF-8) were barren. However, it seems likely that the Minjin Member ranges into the Famennian as we have found diagnostic conodonts of the Famennian, such as Palmatolepis cf. gracilis gracilis in younger parts of the section (Fig. 12, sample BR-C42; Fig. 15b). This species ranges from the Upper rhomboidea biozone (Klapper and Ziegler 1979) to the ?Upper praesulcata biozone (Ji and Ziegler 1993). According to the revised Late Devonian Conodont Zonation by Spalletta et al. (2017), the species ranges from the Palmatolepis gracilis gracilis biozone to the ?Protognathodus kockeli biozone. That means that the Minjin Member in our section has a stratigraphical range from the Middle Devonian (Givetian) to the Upper Devonian (Late Famennian). This unit is covered by siltstone and two thickbedded layers of pyroclastic rock.

In the next unit, we have found conodonts at the base of the Arynshand Formation. Minjin et al. (2001) suggested that a hiatus occurs around the $\mathrm{D} / \mathrm{C}$ boundary. From the sedimentological point of view, Upper Devonian rocks in our section are
Fig. 13 Radiolarians and conodonts found in the Minjin Member: a, b Trilonche cf. T. davidi (Hinde); $\mathbf{a}=$ sample number BR-F-3; $\mathbf{b}=$ sample number BR-F-5; $\mathbf{c}=$ Trilonche sp., sample number BR-F-5; d-k Helenifore $\mathrm{cf}$. H. robustum (Boundy-Sanders and Muchey); $\mathbf{d}-\mathbf{i}=$ sample number BR-F-3; $\mathbf{j}-$ $\mathbf{k}=$ sample number BR-F-4; $\mathbf{l}, \mathbf{m}$ Trilonche cf. T. minax (Hinde), sample number BR-F-6; n, o Polygnathus pollocki Druce, sample BR-F-5; p, q Polygnathus angustidiscus Yongquist, sample BR-F-4. Scale bars $=100 \mu \mathrm{m}$

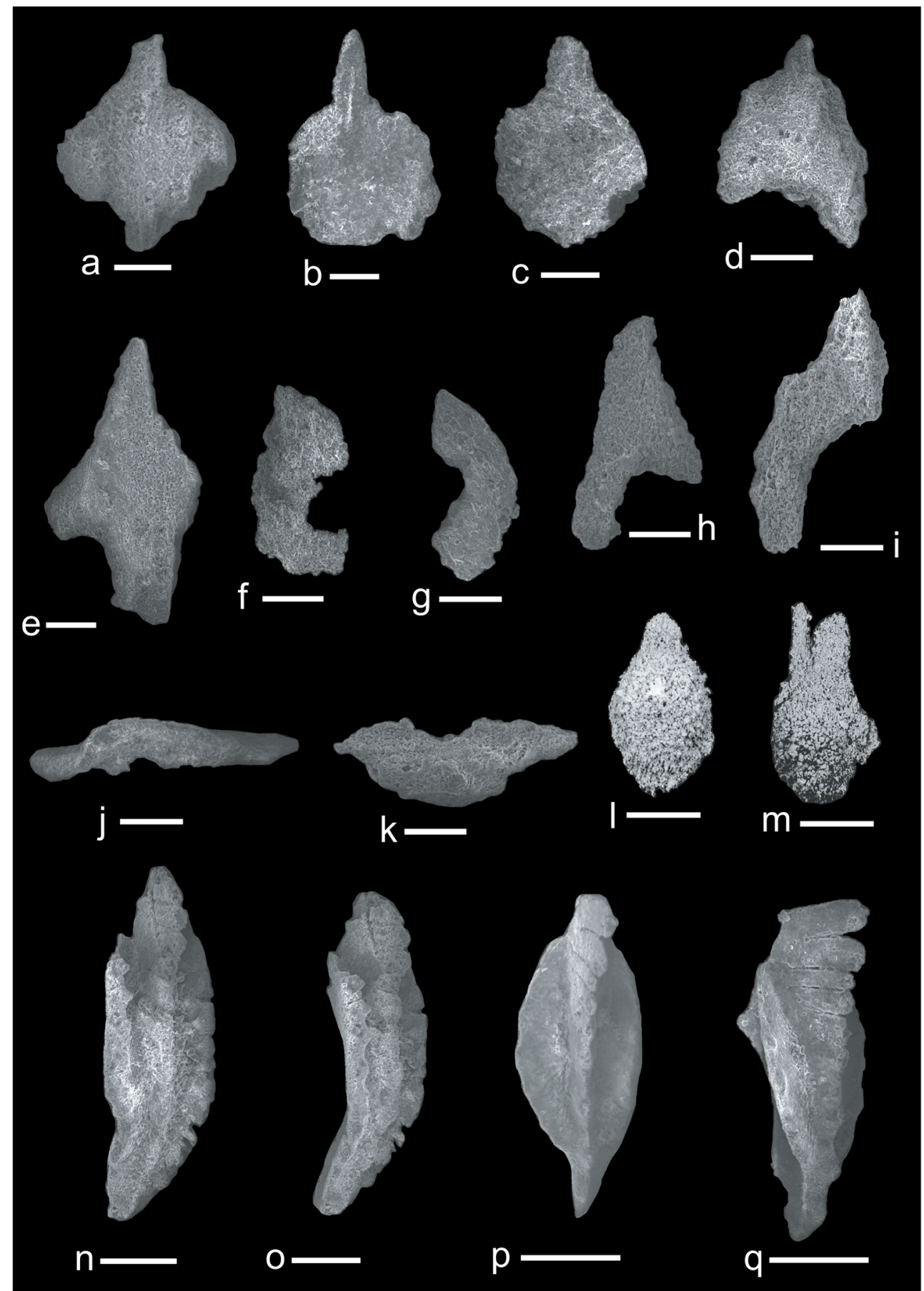


disconformably overlain by Mississippian rock (see next section) which seems to be a result of thrusting rather than a hiatus. Evidence of subaerial exposure and/or non-deposition, which is reported from areas close to this section (Wang et al. 2005), seems unlikely based on facies characteristics of Upper Devonian rocks which represent deep-water facies such as siltstone and radiolarian chert (sample BR-S-29, Fig. 13a).

\section{Arynshand Formation}

This formation was established by Aleseeva (1993) and is widely distributed in the Mushgai area with a thickness of 150 to $250 \mathrm{~m}$. The Arynshand Formation is primarily composed of limestone, but in contrast to earlier publications (e.g., Ariunchimeg and Nyamsuren 2001; Wang et al. 2005), it also contains bentonites, pyroclastic volcanics, crinoidal grainstone, and red shale in the upper part (Figs. 11 and 14c, d). In earlier publications, this formation was interpreted as ranging from Late Devonian to Early Carboniferous (Minjin et al. 1993). In later publications, Minjin et al. (2001), Wang et al. (2005) and Wang and Minjin (2004) concluded that the lower part of the Arynshand Formation at the Bayankhoshuu Ruins section ranges from the sandbergi biozone to the Lower crenulata biozone and that the $\mathrm{D} / \mathrm{C}$ boundary was not exposed in the thin-bedded limestone due to a hiatus between the Arynshand Formation and the underlying rocks of the Botuulkhudag Formation (Minjin Member). In the Murugtsug section nearby (about $300 \mathrm{~m}$ west of this section), the Devonian-Carboniferous transition was reported based on the conodonts (Siphonodella praesulcata and Siphonodella sulcata were found). Unfortunately, the conodonts were not illustrated and thus the $\mathrm{D} / \mathrm{C}$ transition in this area remains questionable. Aristov (1998) reported from the same section even younger conodonts ranging from the duplicata biozone to the Upper crenulata-isosticha biozone (zonation scheme after Sandberg et al. 1978).

The lower part of this formation starts with limestones, thin shale, and a bentonite bed. In the middle part of the Arynshand Formation several layers of pyroclastic rocks and another bentonite occur (Fig. 12). This succession is overlain by grayish, micritic limestone and crinoidal grainstone (sample BR-S-38, Figs. 11 and 14c) at the top. Separating this interval and the massively bedded limestone above, a breccia occurs. Scholle et al. (1993) have shown that timing of solution-breccia formation can be problematic whether the breccias were formed synsedimentary or during late diagenesis. Very early in the diagenetic evolution of sediments, desiccation cracks developed in the host sediment. As a result of incomplete solution collapse, a dense network of fractures is formed (e.g., Assereto and Benelli 1971; Pomoni-Papaioannou and Karakitsios 2002), and owing to progressive evaporite dissolution, an enlargement of the cracks can result to in situ brecciation. The collapse structure in our section can be characterized as a monomict tectonic fault breccia (Fig. 14d-e) which may also lead to subaerial exposure and karst in a later stage. The breccia consists of mainly angular, millimeter- to several decimeter-sized clast-supported and matrix-supported clasts. Strong fracturing concerns the whole rock as well as individual clasts. Microfractures differ in width, orientation, and filling, and the matrix consists of small pieces of rock fragments which are bound together by sparry calcite (Fig. 14d). These features support a fault breccia.

This succession is overlain by red shale which yields some large boulder of older crinoidal grainstone (Fig. 14e, g). It seems likely that this unit represents paleokarst and subaerial exposure in the early Mississippian (close to the Tournaisian/ Visean boundary; see conodont record).

Our biostratigraphic results from recent fieldwork and review of the conodont collection by Wang et al. (2005) differ from the results in earlier publications (see above) and provide a more precise biostratigraphic framework. A formation should be a mappable unit, and thus, the Arynshand Formation starts with the first limestone which lies disconformably upon the Minjin Member (Fig. 12). The first conodont sample BR-C-40 did not yield conodonts, but the following sample BR-C-41 yields Polygnathus cf. longiposticus (Fig. 15c, sample BR-C-41). This species has a stratigraphical range from the ?Bispathodus ultimus biozone to Tournaisian (Spalletta et al., 2017). The next conodonts were found in sample BR-C-42: Palmatolepis cf. gracilis gracilis (Fig. 15b), Polygnathus inornatus (Fig. 15e), and Polygnathus communis cf. renatae (Fig. 15d). Polygnathus cf. gracilis gracilis ranges from the Palmatolepis gracilis gracilis biozone to the ?Protognathodus kockeli biozone (Spalletta et al. 2017), Polygnathus communis cf. renatae ranges from the Bispathodus ultimus biozone to Tournaisian, and Polygnathus inornatus ranges from the Bispathodus costatus biozone to Tournaisian (Spalletta et al. 2017). Thus, this assemblage most probably is late Famennian in age (Lower praesulcata biozone according to the biozonation by Ziegler and Sandberg (1990) or the Bispathodus ultimus biozone published in Spalletta et al. 2017). Sample BR-C-43 (Fig. 15) yields an assemblage including Siphonodella cf. duplicata the name bearing species of the duplicata biozone. Neither Siphonodella sulcata nor Protognathodus species (such as Pr. kuehni or Pr. kockeli) was found which would be helpful to define the D/C boundary. From the sedimentological point of view, there was no evidence of a Hangenberg Crises and related characteristic lithology such as black shales or black limestone (which is not necessarily the case in all D/C sections worldwide and depend on facies, but characteristic lithologies are frequent; Kaiser et al. 2015; Königshof et al. in press), but this part of the section was thrusted and strongly folded. Thus, our interpretation is that the $\mathrm{D} / \mathrm{C}$ boundary is not exposed in this section due to strong tectonic overprint. Sample BR-C-44 yielded Polygnathus cf. tenuiserratus M1 (Fig. 15m) which occurs in the Lower to Upper duplicata biozone (Corradini et al. 2003). The next younger unit was found 
in sample BR-C-47. Bispathodus stabilis (Fig. 15 p), Polygnathus purus purus (Fig. 15s), some Siphonodellid species, and the index species Siphonodella crenulata correspond to the Lower crenulata biozone.

The youngest part documented in this section by conodonts (sample BR-C-50, Fig. 12) represents the Scaliognathus anchoralis-Doliognathus latus biozone. This biozone is defined by the presence of Scaliognathus anchoralis and Doliognathus latus. The latter one was not found, but two subspecies of
Scaliognathus, Scaliognathus anchoralis anchoralis and Scaliognathus anchoralis europensis (Fig. 15q-u), were identified. This unit is covered by red shales with a tectonic breccia at the base suggesting a syntectonic fault breccia, followed by shales and red shales with limestone clasts, which is most likely a result of subaerial exposure around the Tournaisian/Visean boundary. Conodont data suggest that the Arynshand Formation ranges from the Bispathodus ultimus conodont biozone (late Famennian) to the Scaliognathus anchoralis-
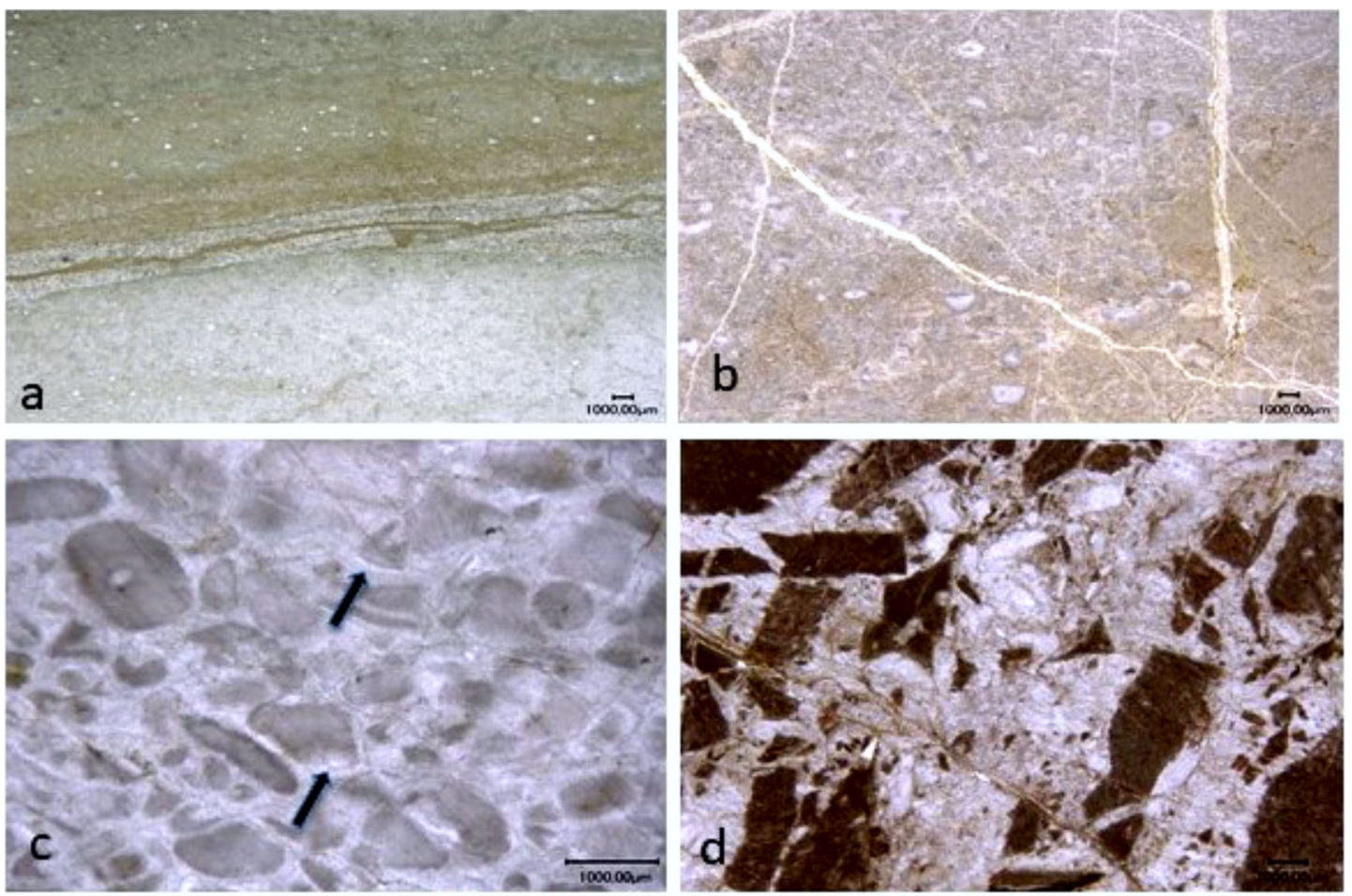
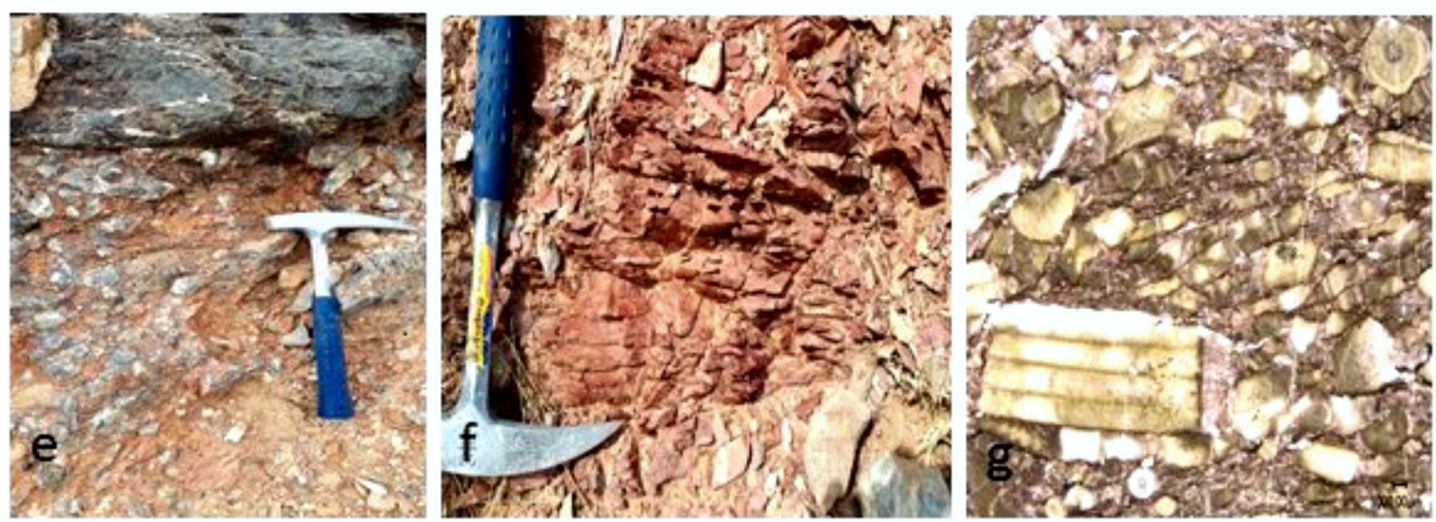

Fig. 14 Microfacies/lithology of the Botuulkhudag Formation, Minjin Member, and examples from the Arynshand Formation: a micritic limestone with radiolarians. In the middle part of the thin section, a thin intercalation of siltstone occurs deposited as distal turbidite or as a result of bottom currents in basinal facies setting (Minjin Member, sample BRS-28); b Wackestone with rare crinoids, base of the Arynshand Formation (Early Mississippian, sample BR-S-31); c moderately sorted crinoid packstone, syntaxial rim cement (arrows) indicate continuous growth of crinoid calcite under burial conditions (sample BR-S-38); d monomict breccia at the upper part of the Arynshand Formation; some calcite veins postdate brecciation (sample BR-S-39); e Field photograph of limestone breccia with red shales; $\mathbf{f}$ red shales at the top of the Arynshand Formation, photo taken around sample BR-F-9; g poorly sorted, densely packed crinoid packstone which shows strong compaction and pressure solution indicated by stylolitic boundaries between crinoid fragments (sample BR-S-38) 
Doliognathus latus biozone (Mississippian, corresponds to the transition of the Tournaisian/Visean boundary in Belgium) in the Bayankhoshuu Ruins section.

\section{Tal Formation}

The Tal Formation is composed of siliciclastic rock and limestone. The formation is distributed in the northern part of the region and has a thickness of $500 \mathrm{~m}$. Lithologically, the Tal
Formation is subdivided into three parts: the lower part (Shand Member) is characterized by fine-grained clastics, $52 \mathrm{~m}$ in thickness; the middle part (Bayankhoshuu Member) is predominantly composed of carbonates with a thickness of $50 \mathrm{~m}$ yielding badly preserved fossils; and the upper part (Muusukhait Member) is composed of dark-gray, black siltstone, clay slate containing pyrite, and fine-grained sandstone with thin bituminous limestone layers, with an exposed thickness of over $300 \mathrm{~m}$. According to Suetenko et al. (1977), the
Fig. 15 Conodonts from Ordovician and Devonian/ Carboniferous: a Walliserodus cf. amplissimus or Hamarodus sp. b Palmatolepis cf. gracilis gracilis Branson \& Mehl,

1934a incomplete and highly altered species. c Polygnathus cf. longiposticus Barnson \& Mehl 1934a. d Polygnathus communis cf. renatae, Corradini et al. 2003. e Polygnathus inornatus Branson \& Mehl, 1934b. f Siphonodella sp. (cf. duplicata?), $\mathbf{g}$ Siphonodella cf. duplicata, $\mathbf{h}$ Bispathodus cf. spinulicostatus (Branson 1934). i Polygnathus sp. j Siphonodella cf. duplicate. $\mathbf{k}$ Gnathodus pseudosemiglaber Thompson \& Fellows, 1970. I Polygnathus cf. longiposticus. m Polygnathus cf. tenuiserratus M1, Corradini et al. 2003. n Siphonodella crenulata Cooper 1939. o Siphonodella sp. p Bispathodus stabilis Branson \& Mehl 1934a. q Scaliognathus cf. anchoralis europensis Lane \& Ziegler 1983. r Siphonodella sp. s Polygnathus purus purus Voges 1959. t Scaliognathus anchoralis anchoralis Barnson \& Mehl 1941. u Scaliognathus anchoralis europensis Lane \& Ziegler 1983. v Polygnathus purus purus Voges, 1959. Scale bars $=$ $100 \mu \mathrm{m}$

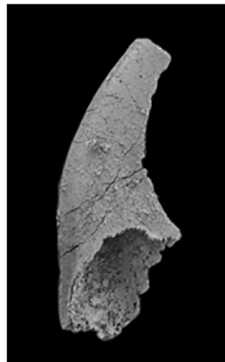

a -

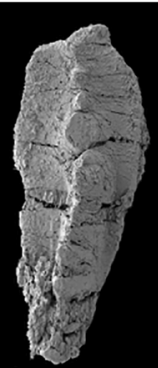

b

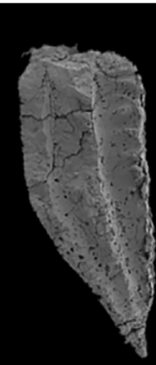

C

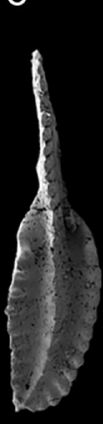

i -

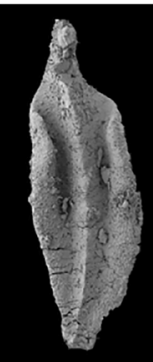

d

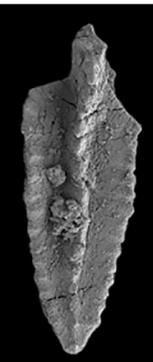

e

-

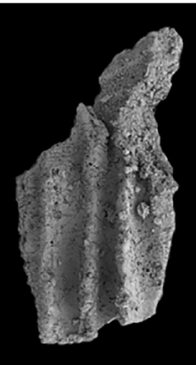

f
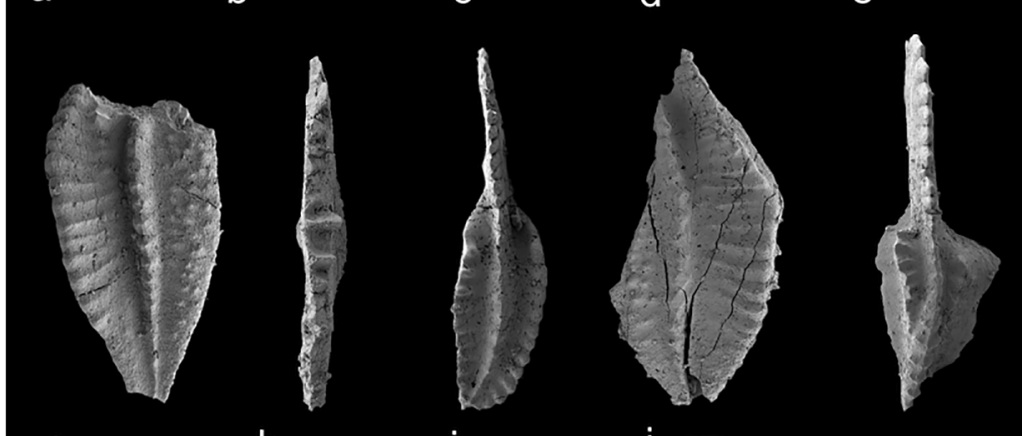

k -

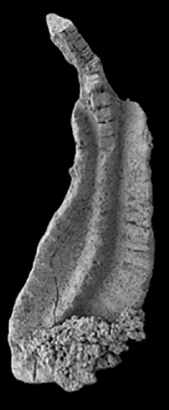

o -

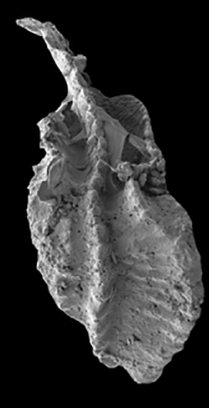

$\mathrm{n}$

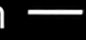

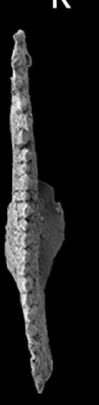

$\mathrm{p}-$
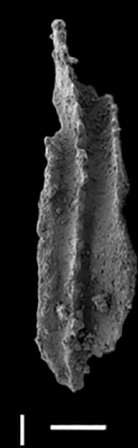

$\mathrm{m}$

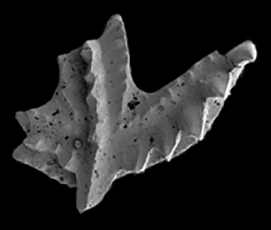

q-
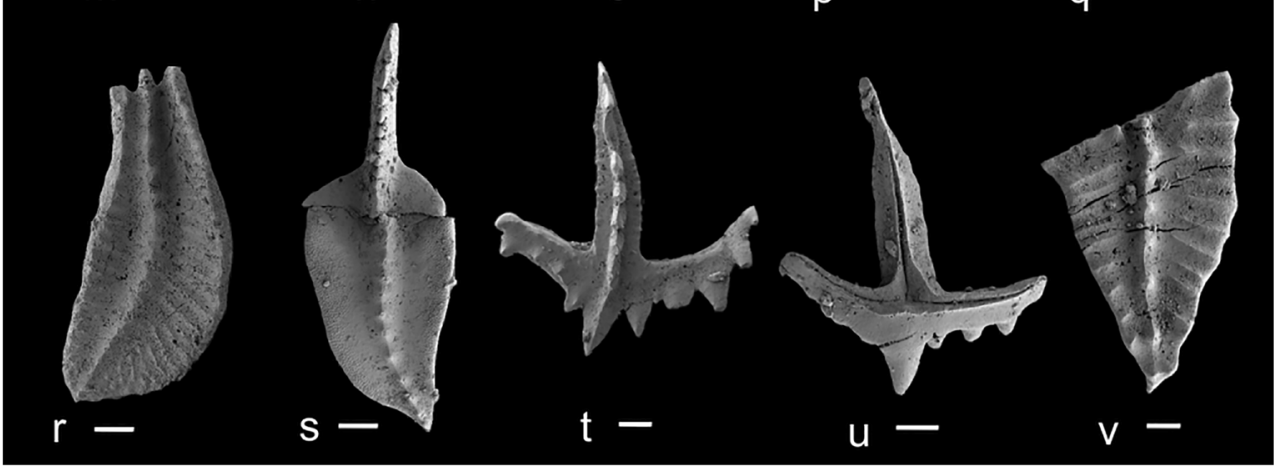
lower part of this formation has tectonic contacts on both sides whereas Nyamsuren (1998) reported that the contact between the Arynshand Formation and the Tal Formation is conformable, which is shown in the Bayankhoshuu Ruins section. The interpretation by Nyamsuren (1998) is not likely as in the upper part of the Arynshand Formation limestone breccias and red shales occur which point to subaerial exposure rather than a continuous succession. The stratigraphical range of the Tal Formation is unclear. Unfortunately, the three conodont samples which were taken from the Tal Formation on the other side of the mountain ridge did not yield conodonts.

\section{Discussion}

All sections are strongly tectonized at all scales from centimeter to kilometer, and many carbonates are diagenetically altered, but not as severely as the western Mongolian sections of the Baruunhuurai Terrane (Munkhjargal, Königshof, Hartenfels et al. this issue). Thrusting at different scales occurs frequently which may explain the thickness differences of some formations in the Bayankhoshuu Ruins area. Tectonic stress and alteration also occur in conodont samples. Some conodont elements exhibit alteration or surface structures which are caused by hydrothermal fluids. Those samples show "high" CAI values (CAI 6) and recrystallization features at the surface and are not useful to estimate palaeotemperatures but provide information on regional metamorphism and tectonic stress (e.g., Epstein et al. 1977, Königshof 2003).

Overall, terrigenous sediments are not common in the Bayankhoshuu Ruins section, indicating deposition some distance from an emergent hinterland. Two intervals of conglomerates with clasts primarily consisting of older carbonate pebbles to cobbles (and larger) indicate subaerial exposure of the carbonates with formation of high-energy deposits likely close to a coastline. Although many of the cobbles are rounded, cobble size is not consistent with long-distance transport. Conglomerates in the Takhuul Member of the Botuulkhudag Formation have both Silurian and Devonian corals in the cobbles.

The Bayankhoshuu Ruins section has at least three distinct intervals of carbonate development-Upper Ordovician/ Lower Silurian, Lower Devonian, and Lower Carboniferous. The presence of a thick carbonate sequence such as in the Carboniferous requires a palaeogeographic position close to a palaeoequatorial realm. Palaeomagnetic results (Safonova et al. 2017) suggest that the Devonian volcanic arc was near the palaeoequator and drifted $40^{\circ}$ to the north which seems unlikely for the early Mississippian. Crinoidal grainstone is most frequent in the Ordovician and less common in Lower Carboniferous carbonates, but benthic fauna is rare with the exception of corals present in distinct layers, but these are not common.
Two distinct types of volcanic activity are observed in the section. Basalts consistent with back arc spreading are dominant in the Middle to Late Devonian of the Bayankhoshuu Ruins section. The Devonian basalts are very thick. The presence of pillow structures in the Devonian basalts indicates active sea floor extrusion. Pyroclastic rocks and bentonites prove periodic subaerial extrusion and occur preferably in the Middle to Late Devonian and are of small importance in the Mississippian. Prolonged volcanic activity particularly in the Late Devonian is reported from many places around the world and has been suggested to be a driver of ecological collapse at the D/C boundary (e.g., Moreno et al. 1996; Paschall et al. 2019; Racki et al. 2018; Racki 2019). Intercalations of deep-water (radiolarian-rich) siltstone and chert indicate multiple periods of sea floor spreading. The section contains more than 20 bentonite layers, some more than $2 \mathrm{~m}$ thick in the outcrop. The bentonites indicate a more distant, more explosive volcanic source likely associated with subduction rather than back arc development.

The succession from the Minjin Member of the Botuulkhudag Formation to the Arynshand Formation (Figs. 8, 10, and 11) is a potentially important sequence. Conodont data from limestone blocks in the basalt prove a Givetian (Middle Devonian) age to the volcanic rocks (Minjin et al. 2001). Although none of us in the field are experts in igneous petrology, we were able to delineate some textural and compositional changes in the volcanic sequence. The lower part of the basalts is finely crystalline with no evidence of pillows. Pillow structures appear above. Basalts in the Minjin Member represent at least two intervals of extrusion as they are separated by a sedimentary sequence some tens of meters thick. Felsic volcaniclastic units are also found in this part of the sequence (Fig. 10). Basalts in the upper part of the Minjin Member show numerous pillow structures, some very large (Fig. 10e). Color changes suggest changes in composition of the magma although this remains to be confirmed by lab work. According to Lamb and Badarch (2001), geochemical data from the pillow lava of the Mandalovoo Terrane show that they were erupted in a subduction zone setting. Volcaniclastic successions which can reach a remarkable thickness (Fig. 11) occur in the Late Devonian part of the Botuulkhudag Formation (Minjin Member). The subaerial to marine volcanic activity within the South Gobi Zone suggests the development of an intra-oceanic basin (Lamb and Badarch 1997). The entire section exhibits different subaerial and submarine volcanic phases (Fig. 16).

A more or less complete section from the basalts in the Minjin Member to the limestone of the Arynshand Formation was pieced together in the field. The sedimentary sequence above the basalts is composed of a deep-water (below storm wave base) succession — siliceous mudstone, siltstone, or chert (Fig. 16). A remarkable thick succession of about $9 \mathrm{~m}$ thick pyroclastic rocks in the upper part of the Minjin Member suggests explosive subaerial eruptions. Radiolarians which have been found in the overlain siliceous siltstone point to a late Frasnian age. Based on 
sedimentological characteristics and biostratigraphical data, it seems likely that the Devonian/Carboniferous transition is not exposed in the Bayankhoshuu Ruins section which can be explained by thrusting.

The lower part of the Arynshand Formation is composed of thin-bedded limestone, micrite with some crinoidal grainstone. Separating this interval and the massively bedded limestone above is a small interval of red shale with a breccia at the base suggesting a syntectonic fault breccia. In contrast to paleokarst collapse structure which are characterized by polymict, angular to subrounded clasts, this sediment is composed of angular to subangular, strongly fractured monomict clasts (reddish marls with small shell hash). Thin sections show that calcite veins clearly postdate brecciation.

The red shales on top of that succession exhibit large rounded blocks of crinoid limestones, and a subaerial exposure/paleokarst seems likely in that case rather than a tectonic breccia. It is probable that subaerial exposure is linked with a remarkable eustatic sea-level drop and/or tectonic processes (terrane collision). The youngest conodonts found in the Arynshand Formation below the fault breccia represent the conodont Scaliognathus anchoralis-Doliognathus latus biozone. A drop in sea level during the early Mississippian (corresponds to the latest Tournaisian or the Tournaisian/ Visean boundary in Belgium = early Mississippian) which resulted in extensive limestone dissolution and karstification at surface and subsurface levels was described by Schönlaub et al. (1991) from the Carnic Alps. This paleokarst is associated with the unconformity that separates the Devonian to
Lower Carboniferous limestone sequences from the overlying flysch deposits of the Hochwipfel Formation. In terms of the currently used conodont zonation, this event occurred during the Scaliognathus anchoralis-Doliognathus latus biozone.

Interestingly, the paleokarst observed in this study coincided with a regressive cycle reported from the Madison Limestone in North America. The Madison Limestone represents a second-order super sequence that internally consisted of six third-order sequences (Westphal et al. 2004; Katz et al. 2007; Oehlert et al. 2019). The beginning of the second-order regressive cycle is roughly correlated with the base of the Scaliognathus anchoralis-Doliognathus latus biozone, but there is no evidence of exposure horizon or karstic surfaces which is similar to coeval sections in Belgium (Hance et al. 2002). Thus, it seems plausible that karstification observed in the early Mississippian of the Bayankhoshuu Ruins section represents a local event. By the end of Tournaisian time, the eastern margin of the Russian Platform experienced uplift, exposure, and increased volcanism associated with collision of volcanic arcs and Uralian microcontinents to the east (Kirikov 1988; Ulmishek 1988). Guy et al. (2014) described various sections in the south Gobi Zones in southern Mongolia such as a section from the Noyon Uul syncline which is in the west of our study area. In their summary of lithostratigraphic units, they have shown an unconformity/ hiatus which occurs in the Early Carboniferous but details on stratigraphy are not given. So, it seems questionable where this event can be linked with the unconformity observed in the Bayankhoshuu Ruins section.
Fig. 16 Stratigraphic chart of formations/members of the Bayankhoshuu Ruins section combined with tectonic and volcanic events (unconformity/hiatus, basalts/pyroclastic deposits) of southern Mongolia, Mandal Ovoo area (Umnugobi Province) based on published data (Minjin et al. 2001; Wang et al. 2003, 2005) and our results. The right column shows a composite lithological log of the investigated sections. The succession is mainly composed of pelagic/hemipelagic sediments and exhibits different subaerial and submarine volcanic phases. For more details, see figures and explanations in the text

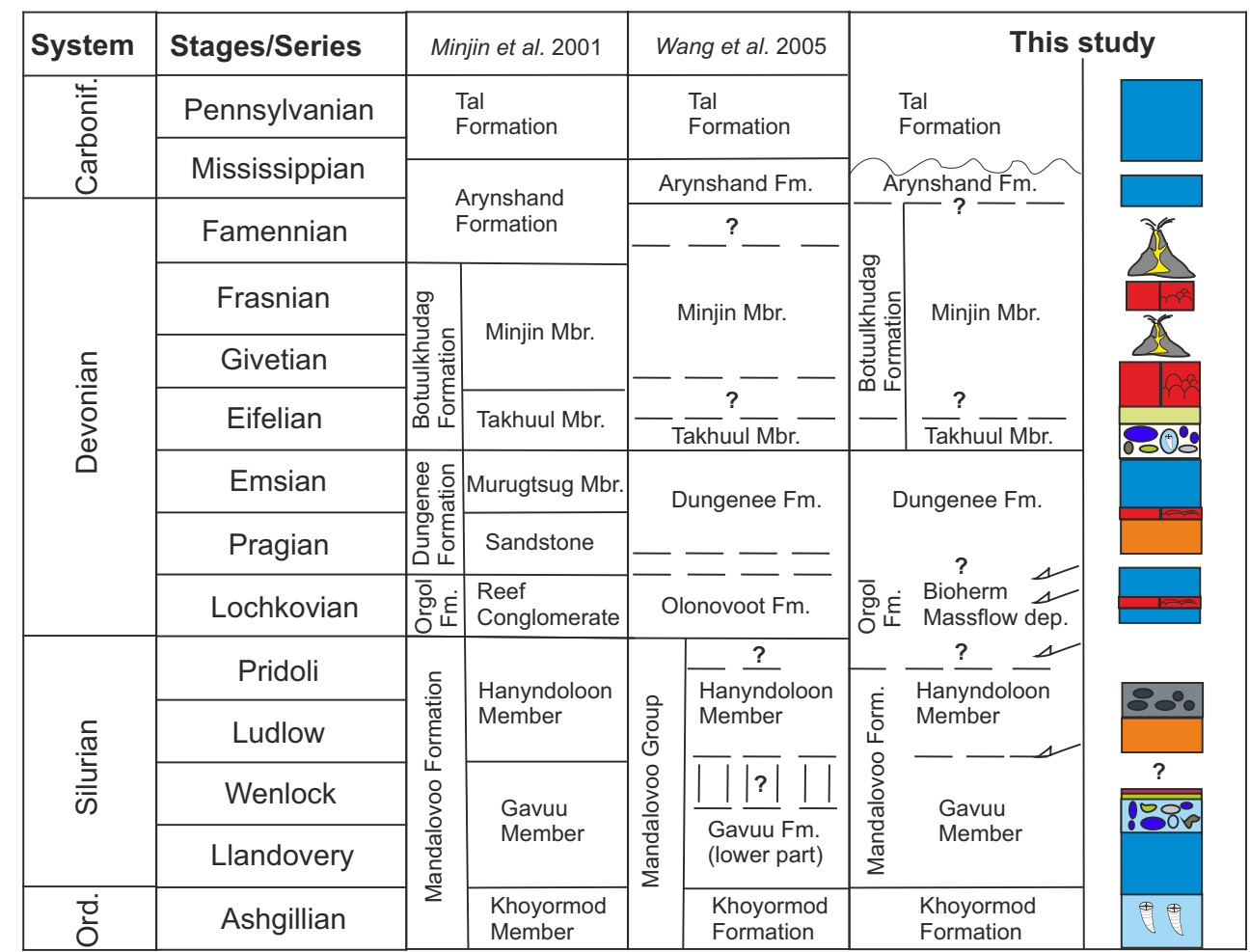


Lower in the section (Siphonodella isosticha-Upper Siphonodella crenulata biozone to Lower Gnathodus typicus biozone), one of the largest $\delta^{13} C_{\text {carb }}$ excursions in the Phanerozoic in the early Mississippian were reported from various regions (e.g., Bruckschen et al. 1999; Saltzmann et al. 2004; Oehlert et al. 2019). As this critical period is also exposed in the studied section (see conodont record above), geochemical studies are necessary to prove evidence of this important $\delta^{13} \mathrm{C}_{\text {carb }}$ excursion in the early Mississippian of the Bayankhoshuu Ruins section.

\section{Conclusions}

- Although many more conodont samples are necessary in order to provide a better biostratigraphic record, this report provides important sedimentological and stratigraphical descriptions from the Bayankhoshuu Ruins section (Mushgai area, southern Mongolian Gobi). We could improve the stratigraphy of some formations such as the Khoyormod Formation, the Botuulkhudag Formation (particularly the Minjin Member), and the Arynshand Formation.

- The Bayankhoshuu Ruins section is characterized by strongly thrusted and folded sequences which contain relatively scarce fossils except some distinct horizons. However, based on this study, the Bayankhoshuu Ruins section ranges from the Late Ordovician (Khoyormod Formation) to the early Mississippian (Arynshand Formation).

- Due to the general rareness of fossils, poor preservation, and strong tectonic overprint, it was not possible to pinpoint Palaeozoic event layers, but we provide more detailed information on the placement of the succession within the Palaeozoic Terrane scheme for Mongolia.

- The Bayankhoshuu Ruins section exposes mainly deepwater (hemipelagic and pelagic) deposits composed of limestones, siltstones, and cherts; shallow-water sediments are less frequent.

- Red shales occur in the lower part of the early Mississippian Arynhand Formation suggesting subaerial exposure/ paleokarst which corresponds to the latest Tournaisian or the Tournaisian/Visean boundary in Belgium. An equivalent of this unconformity was described from the Carnic Alps.

- The marine sedimentary succession is interjected by volcanic rocks-basaltic lava of Silurian and Middle Devonian age and volcaniclastic bentonite and tuff in the Middle to Late Devonian and Mississippian which can reach a remarkable thickness. Deposits of the Bayankhoshuu Ruins section suggest an island arc setting. Overall, deposition likely occurred on either the Mandalovoo or Gurvansayhan Terrane.
- Late Devonian and Mississippian rocks of the Bayankhoshuu Ruins section are not comparable with the shallow-water Hushoot Shiveetiin gol section (Baruunhuurai Terrane) in western Mongolia where a reasonably abundant and diverse macrofauna has been described (Munkhjargal, Königshof, Hartenfels et al. this issue; Crônier et al. this issue; Nazik et al. this issue; Waters et al. this issue), but facies settings of both sections are characterized by very strong volcanic activity, particularly in the Late Devonian.

Acknowledgements Fieldwork in the southern Gobi in Mongolia can be difficult. We acknowledge and appreciate the hard work of our support team, drivers Damdinjamts Gonchigdorj and Bayarjargal Bazarragchaa and cook Baasansuren Gonchigdorj, for making the fieldwork a success. The management of the Olon Ovoot gold mine provided housing during our time in the field. We also acknowledge Byambajargal Bazarragchaa for the use of his Ford SVT Raptor as a field vehicle. Jana Anger provided technical assistance in field processing selected samples of conodonts during the fieldwork. We thank Clive Burrett (Mahasarakham University, Mahasarakham, Thailand) and Uyanga Bold (Mongolian University of Science and Technology, Ulaanbaatar, Mongolia) for their helpful comments and suggestions.

Funding Open Access funding enabled and organized by Project DEAL. A. Munkhjargal received funding from the German Academic Exchange Service (DAAD, Research Grant - Doctoral Programme in Germany, September 01, 2018, to September 01, 2021; 57381412), P. Königshof has received funding from Deutsche Forschungsgemeinschaft (DFG KO1622/19-1). This is a contribution to IUGS/UNESCO Project IGCP 652 ("Reading geologic time in sedimentary rocks").

\section{Compliance with ethical standards}

Conflict of interest The authors declare that they have no conflict of interest.

Open Access This article is licensed under a Creative Commons Attribution 4.0 International License, which permits use, sharing, adaptation, distribution and reproduction in any medium or format, as long as you give appropriate credit to the original author(s) and the source, provide a link to the Creative Commons licence, and indicate if changes were made. The images or other third party material in this article are included in the article's Creative Commons licence, unless indicated otherwise in a credit line to the material. If material is not included in the article's Creative Commons licence and your intended use is not permitted by statutory regulation or exceeds the permitted use, you will need to obtain permission directly from the copyright holder. To view a copy of this licence, visit http://creativecommons.org/licenses/by/4.0/.

\section{References}

Aleseeva, R.E. (1993). Devonian biostratigraphy of Mongolia. Joint Soviet-Mongolian Paleontological Expedition, 44, 33-34 [in Russian].

Aitchison, J. C., Davis, A. M., Stratford, J. M. C., \& Spiller, F. C. P. (1999). Lower and Middle Devonian radiolarian biozonation of the Gamilaroi terrane New England Orogen, eastern Australia. Micropaleontology, 45, 138-162. https://doi.org/10.2307/1486110. 
Aitchison, J. C., Suzuki, N., Caridroit, M., Danelian, T., \& Noble. (2017). Paleozoic radiolarian biostratigraphy. Geodiversitas, 39(3), 503531. https://doi.org/10.5252/g2017n3a5.

Aristov, V. A. (1998). Fossil assemblage from shallow-water Devonian of Eurasia (European Russian, Mongolia). Stratigraphy and Geological Correlation, 6(5), 102-116.

Ariunchimeg, Y., \& Nyamsuren, G. (2001). Upper Famennian and Lower Carboniferous stratigraphy in Mandalovoo and Shin Jinst areas, Mongolia. Transaction Mongolian Science and Technology Geology, 2-3, 24-34.

Assereto, R., \& Benell, F. (1971). Sedimentology of the pre-Cenomanian Formations of the Jebel Gharian, Libya. In Symposium on the geology of Libya (pp. 39-84). Faculty of Science, University of Libya.

Badarch, G., Cunningham, W. D., \& Windley, B. F. (2002). A new subdivision for Mongolia: implications for Phanerozoic crustal growth in Central Asia. Journal of Asian Earth Sciences, 21, 87 110

Balinski, A. (1979). Brachiopods and conodonts from the Frasnian of the Debnik anticline, southern Poland. Palaeontologica Polonica, 39, 3-95.

Barrick, J.E. (1997). Wenlock (Silurian) depositional sequences, eustatic events, and biotic change on the southern shelf of North America. In Paleozoic sequence stratigraphy, biostratigraphy, and biogeography, studies in honor of J. Granville ("Jess") Johnson. Eds. G. Klapper, M.A. Murphy, and J.A. Talent, Geological Society of America, 321, 47-65.

Branson, E. G. (1934). Conodonts from the Hannibal Formation of Missouri. Missouri University Studies, 8, 301-343.

Branson, E. B., \& Mehl, M. G. (1934a). Conodonts from the Grassy Creek shale of Missouri. Missouri University Studies, 8, 171-259.

Bruckschen, P., Oesemann, S., \& Veizer, J. (1999). Isotope stratigraphy of the European Carboniferous: proxy signals for ocean chemistry, climate and tectonics. Chemical Geology, 161, 127-163.

Buslov, M. M., Safonova, I., Watanabe, T., Obut, O. T., Fujiwara, Y., Iwata, K., Semakov, N. N., Sugai, Y., Smirnova, L. V., \& Kazansky, Y. (2001). Evolution of the Paleo-Asian Ocean (Altai-Sayan Region, Central Asia) and collision of possible Gondwana-derived terranes with the southern marginal part of the Siberian continent. Geosciences Journal, 5(3), 203-224. https://doi.org/10.1007/ BF02910304

Chlupác, I., \& Kukal, Z. (1986). Reflection of possible global Devonian events in the Barrandian area, C.S.S.R. In O. Walliser (Ed.), Global bio-events, Lecture Notes in Earth Science, 8, 169-179.

Cooper, C. L. (1939). Conodonts from a Bushberg-Hannibal horizon in Oklahoma. Journal of Paleontology, 13, 379-422.

Corradini, C., Barca, S., \& Spalletta, C. (2003). Late Devonian-Early Carboniferous conodonts from the "Clymeniae limestones" of SE Sardinia (Italy). Courier Forschungsinstitut Senckenberg, 245, 227 253.

Corriga, M. G., Corradini, C., \& Ferretti, A. (2009). Silurian conodonts from Sardinia: an overview. Rediconti della Società Paleontologica Italiana, 3(1), 95-107.

Crônier, C., Ariuntogos, M., Königshof, P., Waters, J., \& Carmichael, S.K. (this issue). Late Devonian (Famennian) phacopid trilobites from western Mongolia. Palaeobiodiversity and Palaeoenvironments https://doi.org/10.1007/s12549-020-00449-w.

Dobretsov, N. L., Berzin, N. A., Buslov, M. M., \& Ermakov, V. D. (1995). General aspects of the Altai region interrelationships between its basement pattern and neotectonic structural development. Russian Geology and Geophysics, 36(10), 3-15.

Donskaya, T. V., Gladkochub, D. P., \& Mazukabzov, A. M. (2013). Late Paleozoic-Mesozoic subduction-related magmatism at the southern margin of the Siberian continent and the 150 million-year history of the Mongol-Okhotsk Ocean. Journal of Asian Earth Sciences, 62, 79-97. https://doi.org/10.1016/j.jseaes.2012.07.023.
Druce, E. C. (1976). Conodont biostratigraphy of the Upper Devonian reef complexes of the Canning Basin, western Australia. Australian Bureau of Resources, Geology and Geophysics, Bulletin, 158, 1303.

Epstein, A. G., Epstein, J. B., \& Harris, L. D. (1977). Conodont colour alteration - an index to organic metamorphism. Geological Survey of America, Professional Paper, 995, 1-27.

Ferretti, A., \& Serpagli, E. (1999). Late Ordovician conodont faunas from southern Sardinia, Italy: biostratigraphic and paleogeographic implications. Bollettino della Societa Paleontologica Italiana, 37(2), 215-236.

Flügel, E. (2004). Microfacies of carbonate rocks. Berlin: Springer.

Folk, R. L. (1954). The distinction between grain size and mineral composition in sedimentary-rock nomenclature. Journal of Geology, 62(4), 344-359. https://doi.org/10.1086/626171.

Foreman, H. P. (1963). Upper Devonian Radiolaria from the Huron member of the Ohio shale. Micropaleontology, 9, 267-304.

Guy, A., Schulmann, K., Clauer, N., Hasalova, P., Seltmann, R., Armstrong, R., Lexa, O., \& Benedicto, A. (2014). Late PaleozoicMesozoic tectonic evolution of the Trans-Altai and South Gobi Zones in southern Mongolia based on structural and geochronological data. Gondwana Research, 25(1), 309-337. https://doi.org/10. 1016/j.gr.2013.03.014.

Hance, P. L., Devuyst, F.-X., \& Poty, E. (2002). Sequence stratigraphy of the Belgian Lower Carboniferous - tentative correlation with the British Isles. In L. V. Hills, C. M. Henderson, \& E. W. Bamber (Eds.), Carboniferous and Permian of the world. Memoir Canadian Society of Petroleum Geologist, 19, 41-51.

Hartenfels, S. (2011). Die globalen Annulata-Events und die DasbergKrise (Famennium, Oberdevon) in Europa und Nord-Afrika hochauflösende Conodonten-Stratigraphie, Karbonat-Mikrofazies, Paläoökologie und Paläodiversität. Münsterische Forschungen zur Geologie und Paläontologie, 105, 17-527.

Helo, C., Hegner, E., Kröner, A., Badarch, G., Tomurtogoo, O., Windley, B. F., \& Dulski, P. (2006). Geochemical signature of Paleozoic accretionary complexes of the Central Asian Orogenic Belt in South Mongolia: constraints on arc environments and crustal growth. Chemical Geology, 227(2006), 236-257. https://doi.org/ 10.1016/j.chemgeo.2005.10.003.

Jeppson, L., \& Anehus, R. (1995). A buffered formic acid technique for conodont extraction. Journal of Paleontology, 69(4), 790-794.

Ji, Q., \& Ziegler, W. (1993). The Lali section: an excellent reference section for Late Devonian in south China. Courier Forschungsinstitut Senckenberg, 157, 1-183.

Johnson, M. E. (1996). Stable cratonic sequences and a standard for Silurian eustasy. In Special Paper 306, Paleozoic sequence stratigraphy; views from the North American Craton. https://doi.org/10. 1130/0-8137-2306-X.203.

Johnson, M. E. (2006). Relationship of Silurian sea-level fluctuations to oceanic episodes and events. GFF, 128, 115-121. https://doi.org/10. 1080/11035890601282115.

Johnson, J.G., \& Sandberg, C.A. (1989). Devonian eustatic events in the Western United States and their biostratigraphic responses, in A.F. McMillan Embry, \& D.J. Glass, (eds.), Devonian of the World: Canadian Society of Petroleum Geologists Memoir, 14(3), 171179.

Johnson, J. G., Klapper, G., \& Sandberg, C. A. (1985). Devonian eustatic fluctuations in Euramerica. Geological Society of America Bulletin, $96,567-587$

Kaiser, S.I., Aretz, M., \& Becker, R.T. (2015). The global Hangenberg Crisis (Devonian-Carboniferous transition): review of a first-order mass extinction, 387-437. In Eds. R.T., Becker, P., Königshof, \& C.E., Brett. Devonian Climate, Sea Level and Evolutionary Events. Geological Society, Special Publication 423. https://doi.org/10. 1144/SP423.9. 
Katz, D. A., Buoniconti, M. R., Montanez, I. P., Swart, P. K., Eberli, G. P., \& Smith, L. B. (2007). Timing and local perturbations to the carbon pool in the lower Mississippian Madison Limestone, Montana and Wyoming. Palaeogeography, Palaeoclimatology, Palaeoecology, 256, 231-253.

Kirikov, V. P. (1988). Devonian period in evolution of the Russian Platform. In N. J. McMillan, A. F. Embry, \& D. J. Glass (Eds.), Devonian of the world, volume I: Regional syntheses. Canadian Society of Petroleum Geologist, Memoir, 14, 513-525.

Klapper, G., \& Murphy, M. A. (1975). Silurian-Lower Devonian conodont sequence in the Roberts Mountains Formation of central Nevada. Geological Sciences, 111, 1-62.

Klapper, G., \& Ziegler, W. (1979). Devonian conodont biostratigraphy. In M. R. House, C. T. Scrutton, \& M. G. Bassett (Eds.), The Devonian system, Palaeontology 23, 199-224.

Königshof, P. (2003). Conodont deformation patterns and textural alteration in Paleozoic conodonts: Examples from Germany and France. Senckenbergiana Lethaea, 83(1/2), 149-156.

Königshof, P., Bahrami, A., \& Kaiser, S. I. (in press). DevonianCarboniferous boundary sections in Iran. In M. Aretz \& C. Corradini (Eds.), Global review of the Devonian-Carboniferous boundary, Palaeobiodiversity and Palaeoenvironments. https://doi. org/10.1007/s12549-020-00438-z.

Kröner, A., Kovach, V., Belousova, E., Hegner, E., Armstrong, R., Dolgopolova, A., Seltmann, R., Alexeiev, D. V., Hoffmann, J. E., Wong, J., Sun, M., Cai, K., Wang, T., Tong, Y., \& Wilde, S. A. (2014). Reassessment of continental growth during the accretionary history of the Central Asian Orogenic Belt. Gondwana Research, $25,103-125$.

Lamb, M. A., \& Badarch, G. (1997). Paleozoic sedimentary basins and volcanic arc systems of southern Mongolia: New stratigraphic and sedimentological constrains. International Geology Review, 39, 542-576.

Lamb, M. A., \& Badarch, G. (2001). Paleozoic sedimentary basins and volcanic arc systems of southern Mongolia: New geochemical and petrographic constraints. In M. S. Hendrix \& G. A. David (Eds.), Paleozoic and tectonic evolution of Central Asia: From continental assembly to intracontinental deformation, Boulder, Colorado. Geological Society of America Memoir 194, 117-149.

Lane, H. R., \& Ziegler, W. (1983). Taxonomy and phylogeny of Scaliognathus Branson \& Meh1, 1941 (Conodonta, Lower Carboniferous). Senckenbergiana Lethaea, 64(199-2), 25.

Lane, H. R., Sandberg, C., \& Ziegler, W. (1980). Taxonomy and phylogeny of some Lower carboniferous conodonts and preliminary standard post - Siphonodella zonation. Geologica and Palaeontologica, 14, 117-164.

Loydell, D. K., Männik, P., \& Nestor, V. (2003). Integrated biostratigraphy of the Silurian of the Aizpute-41 core, Latvia. Geological Magazine, 147, 253-280. https://doi.org/10.1017/ S0016756802007264.

Minjin, C., Badarch, G., \& Tungalag, F. (1993). Stratigraphy of the Shine Jinst Paleozoic deposits. Mongolian Technical University. Scientific Transactions, 3(18), 3-19 (in Mongolian).

Minjin, Ch., \& Tumenbayar, B. (2001). The guidebook, abstract \& Ordovician Silurian correlation chart for the joint field meeting of IGCP 410 and IGCP 421.

Minjin, C., Sersmaa, G., Ariunchimeg, Y. A., Gereltsetseg, L., Undarya, J., Tumenbayar, B., \& Bolortsetseg, M. (2001). The guide book, abstract and Ordovician - Silurian correlation chart for the joint field meeting of IGCP 410 and IGCP 421 in Mongolia. Part II. Mongolian field guide, pp. 12-90.

Moreno, C., Sierra, S., \& Saez, R. (1996). Evidence for catastrophism at the Famennian-Dinantian boundary in the Iberian Pyrite Belt. Geological Society London Special Publications, 107(1), 153-162. https://doi.org/10.1144/GSL.SP.1996.107.01.12.
Munkhjargal, A., Königshof, P., Hartenfels, S., Jansen, U., Nazik, A., Carmichael, S. K., Waters, J. A., Sersmaa, G., Crônier, C., Ariunchimeg, Y., Paschall, O., \& Dombrowski, A. (this issue). The Hushoot Shiveetiin gol section (Baruunhuurai Terrane): Sedimentology and facies from a Late Devonian island arc setting. Palaeobiodiversity and Palaeoenvironments. https://doi.org/10. 1007/s12549-020-00445-0.

Murphy, M. A., Valenzuela-Rios, J. I., \& Carls, P. (2004). On classification of Pridoli (Silurian)-Lochkovian (Devonian) Spathognathodontidae (conodonts). University of California, Riverside Campus Museum Contribution, 6, 1-25.

Narkiewicz, K., \& Bultynck, P. (2016). Taxonomy and biostratigraphic significance of Icriodus orri Klapper and Barrick and related Middle Devonian conodont species. Journal of Paleontology, 90(6), 1-16. https://doi.org/10.1017/jpa.2016.41.

Nazarov, B. B. (1975). Albaillellidea i Paleoscenidiidae iz verkhnedevonskikh otlozhoniy yuzhnogo urala. Trudy VSEGEI $n$. s., 226, 41-47 [in Russian].

Nazik, A., Königshof, P., Ariuntogos, A., Waters, J.A., \& Carmichael, S.K. (this issue). Late Devonian ostracods from the Late Devonian Hushoot Shiveetiin gol section (Baruunhuurai Terrane, western Mongolia) and their palaeoenvironmental implication and palaeobiogeographic relationship. Palaeobiodiversity and Palaeoenvironments. https://doi.org/10.1007/s12549-020-00446-z.

Nestor, V., Einasto, R., \& Loydell, D.K. (2002). Chitinozoan biostratigraphy and lithological characteristics of the Lower and Upper Visby boundary beds in the Ireviken 3 section, Northwest Gotland. Proceedings of the Estonian Academy of Sciences Geology, 51, 215-226.

Nyamsuren, G. (1998). New formation in South Mongolia. Mongolian Geoscientist, 9, 1-50.

Oehlert, A. M., Swart, K. P., Eberli, G. P., Evans, S., \& Frank, T. D. (2019). Multi-proxy constraints on the significance of covariant $\delta^{13} \mathrm{C}$ values in carbonate and organic carbon during early Mississippian. Sedimentology, 66, 241-261.

Paschall, O. C., Carmichael, S. K., Königshof, P., Waters, J. A., Ta, P. H., Komatsu, T., \& Dombrowski, A. (2019). The Hangenberg event in Vietnam: Sustained ocean anoxia with a volcanic trigger? Global and Planetary Change, 175, 64-81. https://doi.org/10.1016/j. gloplacha.2019.01.021.

Pettijohn, F. J., Potter, P. E., \& Siever, R. (1973). Sand and sandstone (p. 617). Berlin: Springer-Verlag.

Pomoni-Papaioannou, F., \& Karakitsios, V. (2002). Facies analysis of the Trypali carbonate unit (Upper Triassic) in Central-Western Crete (Greece): An evaporite formation transformed into solutioncollapse breccias. Sedimentology, 49, 1113-1132.

Racki, G. (1992). Evolution of the bank to reef complex in the Devonian of the Holy Cross Mountains. Acta Palaeontologica Polonica, $37(2 / 4), 87-182$.

Racki, G. (2019). Volcanism as a prime cause of mass extinctions: Retrospectives and perspectives. In T. Adatte, D. P. G. Bond, \& G. Keller (Eds.), Mass extinctions, volcanism, and impacts: New developments. Geological Society of America Special Paper, 544. https://doi.org/10.1130/2019.2544(01.

Racki, G., Rakociński, M., \& Marynowski, L. (2018). Anomalous Upper Devonian mercury enrichments: Comparison of inductively coupled plasma-mass spectrometry (ICPMS) and AAS analytical data. Geology Quarterly, 62(3), 487-495. https://doi.org/10.7306/gq. 1419.

Rodrigues-Canero, R., Martin-Algarra, A., Sarmiento, G. N., \& NavasParejo, P. (2010). First Late Ordovician conodont fauna in the Betic Cordillera (South Spain): A palaeobiographical contribution. Terra Nova, 22(5), 330-340. https://doi.org/10.1111/j.1365-3121.2010. 00954.x.

Ruzhentsev, S. V., Pospeleov, I. I., \& Badarch, G. (1992). Tectonics of Baruunkhuurai Basin, Mongolia. Geotectonics, 22(1), 67-77. 
Safonova, I., Kotlyarov, A., Krivonogov, S., \& Xiao, W. (2017). Intraoceanic arcs of the Paleo-Asian Ocean. Gondwana Research, 50, 167-194. https://doi.org/10.1016/j.gr.2017.04.005.

Saltzmann, M. R., Groessens, E., \& Zhuravlev, A. V. (2004). Carbon cycle models based on extreme changes in $\delta^{13} \mathrm{C}$ : An example from the lower Mississippian. Palaeogeography, Palaeoclimatology, Palaeoecology, 213, 359-377.

Salzmann, M. R. (2001). Silurian $813 \mathrm{C}$ stratigraphy: A view from North America. Geology, 29, 671-674.

Sandberg, C. A., Ziegler, W., \& Bultynck, P. (1989). New standart conodont zones and early Ancyrodella phylogeny across the MiddleUpper Devonian boundary. Courier Forschungsinstitute Senckenberg, 110, 195-230.

Sandberg, C. A., Ziegler, W., Leuteritz, K., \& Brill, S. M. (1978). Phylogeny, speciation, and zonation of Siphonodella (Conodonta, Upper Devonian and Lower Carboniferous). Newsletters on Stratigraphy, 7(2), 102-120.

Scholle, P. A., Stemmerik, L., Ulmer-Scholle, D. S., Di Liegro, G., \& Henk, F. H. (1993). Palaeokarst-influenced depositional and diagenetic patterns in Upper Permian carbonates and evaporites, Karstrygen area, central East Greenland. Sedimentology, 40, 895918.

Schönlaub, H. P., Klein, P., Magaritz, M., Rantitsch, G., \& Scharbert, S. (1991). Lower Carboniferous Paleokarst in the Carnic Alps. Facies, $25,91-118$

Spalletta, C., Perri, M. C., Over, D. J., \& Corradini, C. (2017). Famennian (Upper Devonian) conodont zonation: Revised global standard. Bulletin of Geosciences, 91, 31-57. https://doi.org/10.3140/bull. geosci.1623.

Stern, R. J., \& Scholl, D. W. (2010). Yin and yang of continental crust creation and destruction by plate tectonic processes. International Geology Review, 52, 1-31. https://doi.org/10.1080/ 00206810903332322.

Suetenko, O. D., Sharkova, T. T., \& Ulitina, K. M. (1977). Paleozoic stratigraphy and fauna of the eastern spurs of Gobian Altai (Mandal-Ovoo massif). Transactions Joint Soviet-Mongolian Paleontological Expedition, 5, 32-48 (in Russian).

Thassanapak, H., Udchachon, M., \& Burrett, C. (2012). Devonian radiolarians and tentaculitids from Central Laos. Journal of Asian Earth Science, 60, 104-113. https://doi.org/10.1016/j.jseaes.2012.08.002.

Thompson, T. L., \& Fellows, L. D. (1970). Stratigraphy and conodont stratigraphy of Kinderhookian and Osagean rocks of south western Missouri and adjacent areas. Missouri Geological Survey and Water Resources Report of Investigations, 39, 3-263.

Tucker, M. E. (2001). Sedimentary petrology: An introduction to the origin of sedimentary rocks. Oxford (3rd ed.p. 262).

Ulmishek, G. F. (1988). Upper Devonian-Tournaisian facies and oil resources of the Russian cratons eastern margin. In N. J. McMillan, A. F. Embry, \& D. J. Glass (Eds.), Devonian of the world, volume I: Regional syntheses. Canadian Society of Petroleum Geologist, Memoir, 14, 527-549.

Voges, A. (1959). Conodonten aus dem Unterkarbon I and II (Gattendorfia und Pericyclus-Stufe) des Sauerlandes. Paläontologische Zeitschrift, 3, 266-314.

Vorozhbitov, A. M. (1997). Conodonts from the Yarovian Horizon (Lower Silurian) of Gornyi Altai. Stratigraphy and Geological Correlation, 4(1), 101-105 (in Russian).

Walliser, O. H. (1996). Global events in the Devonian and Carboniferous. In O. H. Walliser (Ed.), Global events and event stratigraphy in the Phanerozoic (pp. 225-250). Berlin: Heidelberg, Springer.

Wang, C.-Y., \& Chuluun, M. (2004). Early Carboniferous age for Arynshand Formation, Mongolian South Gobi, based on conodonts. Alcheringa: An Australasian Journal of Palaeontology, 28(2), 433440. https://doi.org/10.1080/03115510408619293.
Wang, C. Y., \& Minjin, C. (2004). Early carboniferous age for Arynshand Formation, Mongolian South Gobi, based on conodonts. Alcheringa Australasian Journal of Palaeontology, 28(2), 433-440. https://doi.org/10.1080/03115510408619293.

Wang, Y. J., Aitchison, J. C., \& Luo, H. (2003a). Devonian radiolarian faunas from South China. Micropaleontology, 49(2), 127-145.

Wang, C. Y., Ziegler, W., Minjin, C., Sersmaa, G., Munchtsetseg, J., Gereltsetseg, L., \& Izokh, N. (2003b). The first discovery of the earliest Devonian conodont zonal fossil from the "Gavu Member" in Mushigai area of South Gobi, Mongolia. Journal of Geoscientific Research in Northeast Asia, 6(1), 14-20.

Wang, C. Y., Weddige, K., \& Minjin, C. (2005). Age revision of some Palaeozoic strata of Mongolia based on conodonts. Journal of Asian Earth Sciences, 25, 759-771.

Waters, J. A., Waters, J. W., Königshof, P., Carmichael, S. K., \& Ariuntogos, M. (this issue). Famennian crinoids blastoids (Echinodermata) from Mongolia. Palaeobiodiversity and Palaeoenvironments. https://doi.org/10.1007/s12549-020-00450-3.

Westphal, H., Eberli, G. P., Smith, L. B., Grammer, G. M., \& Kislak, J. (2004). Reservoir characterization of the Mississippian Madison Formation, Wind River basin, Wyoming. The American Association of Petroleum Geologists Bulletin, 4, 405-432.

Wilson, I. G. (1975). Carbonate facies in geologic history (p. 471). Berlin: Springer-Verlag.

Windley, B. F., Alexeiev, D., Xiao, W., Kröner, A., \& Badarch, G. (2007). Tectonic models for accretion of the Central Asian Orogenic Belt. Journal of the Geological Society, 164, 31-47. https://doi.org/10.1144/0016-76492006-022.

Wonganan, N., \& Caridroit, M. (2005). Middle and Upper Devonian radiolarian faunas from Chiang Dao area, Chiang Mai province, northern Thailand. Micropaleontology, 51(1), 39-57.

Xiao, W., \& Santosh, M. (2014). The western Central Asian orogenic belt: A window to accretionary orogenesis and continental growth. Gondwana Research, 25(4), 1429-1444. https://doi.org/10.1016/j. gr.2014.01.008.

Xiao, W. J., Huang, B. C., Han, C. M., Sun, S., \& Li, J. L. (2010). A review of the western part of the Altaids: A key to understanding the architecture of accretionary orogens. Gondwana Research, 18(2-3), 253-273. https://doi.org/10.1016/j.gr.2010.01.007.

Yang, G., Li, Y., Tong, L., \& Yang, B. (2015). Oceanic Island basalts from the Darbut and Karamay Ophiolitic Mélange in West Junggar (NW China): Product of a Middle Devonian mantle plume? Acta Geologica Sinica, 89, 105-106. https://doi.org/10.1111/1755-6724. 1230863.

Yang, G., Li, Y., Tong, L., Wang, Z., Duan, F., Xu, Q., \& Li, H. (2019). An overview of oceanic island basalts in accretionary complexes and seamounts accretion in the western Central Asian orogenic belt. Journal of Asian Earth Sciences, 179, 385-398. https://doi.org/10. 1016/j.jseaes.2019.04.011.

Zhang, S., Jowett, M. S., \& Barnes, C. R. (2017). Hirnantian (Ordovician) through Wenlock (Silurian) conodont biostratigraphy, bioevents, and integration with graptolite biozones, Cape Phillips formation slope facies, Cornwallis Island, Canadian Arctic Islands. Canadian Journal of Earth Sciences, 54(9), 936-960. https://doi.org/10.1139/ cjes-2017-0023.

Ziegler, W., \& Sandberg, C. A. (1990). The Late Devonian standard conodont zonation. Courier Forschungsinstitut Senckenberg, 121, $1-115$.

Zonenshain, L. P., Suetenko, O. D., Jamyandamba, L., \& Eenjin, G. (1975). Structure of the axial part of south Mongolian eugeosyncline in the Dzolen range. Geotectonics, 4, 28-44.

Publisher's note Springer Nature remains neutral with regard to jurisdictional claims in published maps and institutional affiliations. 